NBER WORKING PAPER SERIES

\title{
RISK SHIFTING VERSUS RISK MANAGEMENT: INVESTMENT POLICY IN CORPORATE PENSION PLANS
}

\author{
Joshua Rauh \\ Working Paper 13240 \\ http://www.nber.org/papers/w13240 \\ NATIONAL BUREAU OF ECONOMIC RESEARCH \\ 1050 Massachusetts Avenue \\ Cambridge, MA 02138 \\ July 2007
}

I thank James Wang and Michael Wong for excellent research assistance. I am grateful to John Birge, John Campbell, Murillo Campello, Chris Crevier, Mike Faulkender, Sean Finucane, Charles Hadlock, Dirk Jenter, Steve Kaplan, Vicky Kiosse, Gordon Latter, Deborah Lucas, Francisco Perez-Gonzalez, Mitchell Petersen, James Poterba, Michael Roberts, Antoinette Schoar, Berk Sensoy, Morten Sørensen, Per Strömberg, Amir Sufi, Michael Weisbach, Steve Zeldes, an anonymous referee, and seminar participants at MIT Sloan, the 2006 Corporate Finance Conference at the Washington University Olin School of Business, the 2006 NBER Corporate Finance Summer Institute, and the 2006 UBS Pensions Research Programme Conference at the London School of Economics for helpful comments and discussions. I thank seminar participants at the Chicago GSB finance faculty lunch, the European Central Bank, the University of Illinois, and Michigan State University for comments on an earlier version of this work entitled "Who Manages Pension Fund Risk?" The views expressed herein are those of the author(s) and do not necessarily reflect the views of the National Bureau of Economic Research.

(C) 2007 by Joshua Rauh. All rights reserved. Short sections of text, not to exceed two paragraphs, may be quoted without explicit permission provided that full credit, including $\odot$ notice, is given to the source. 
Risk Shifting versus Risk Management: Investment Policy in Corporate Pension Plans

Joshua Rauh

NBER Working Paper No. 13240

July 2007

JEL No. G23,G31,G32,H32

\begin{abstract}
$\underline{\text { ABSTRACT }}$
The asset allocation of defined benefit pension plans is a setting where both risk shifting and risk management incentives are likely be present. Empirically, firms with poorly funded pension plans and weak credit ratings allocate a greater share of pension fund assets to safer securities such as government debt and cash, whereas firms with well-funded pension plans and strong credit ratings invest more heavily in equity. These relations hold both in the cross-section and within firms and plans over time. The incentive to limit costly financial distress plays a considerably larger role than risk shifting in explaining variation in pension fund investment policy among U.S. firms.
\end{abstract}

Joshua Rauh

Graduate School of Business

University of Chicago

5807 South Woodlawn Avenue

Chicago, IL 60637

and NBER

jrauh@ChicagoGSB.edu 
Corporations with some probability of defaulting on their debt face conflicting incentives with respect to the management of cash flow risks. On the one hand, shocks to cash flows for financially constrained firms can lead to bankruptcy (Smith and Stulz (1985)) or to the inability to take profitable investment projects in the future (Mayers and Smith (1987), Froot, Scharfstein, and Stein (1993)). In contrast, the theory of asset substitution (Jensen and Meckling (1976)) suggests that managers can increase the value of shareholders' equity by raising the volatility of the firm's assets when there is a significant probability of default. In this paper I empirically examine these conflicting motives in a setting where both risk shifting and risk management incentives are likely to be present: investment policies of defined benefit (DB) pension plans sponsored by U.S. corporations.

Since Sharpe (1976) and Treynor (1977), it has been argued that the institutional structure of DB pensions in the U.S. and the control that management exercises over pension fund asset allocation create moral hazard incentives for firms to underfund pension plans and invest the assets in risky securities. The liabilities of a DB plan resemble regular corporate debt in that limited liability protects shareholders from having to transfer or liquidate non-corporate assets to compensate the creditors (or workers) in the event of bankruptcy. If the assets perform well and the firm avoids bankruptcy, then the resulting improvement in pension funding reduces the need to fund the pension out of liquid corporate assets. Furthermore, since the creation of the federal Pension Benefit Guaranty Corporation (PBGC) in 1974, if a firm enters bankruptcy with insufficient pension assets to cover its liabilities to workers, the U.S. government provides plan recipients with their annual pensions up to a statutory maximum amount. The security the PBGC receives is the firm's dedicated pension assets, and the PBGC has a low priority in bankruptcy thereafter, so that general corporate assets enjoy some protection.

However, an important constraint on this moral hazard is that should the firm avoid bankruptcy but face poor performance in its pension fund, it must continue to fund the pension plan with liquid resources. The Employee Retirement Income Security Act (ERISA) of 1974 and several rounds of later legislation established a system of mandatory pension contributions, intended to ensure adequate funding of DB pension plans. Such cash requirements increase the probability that the firm will default on its 
regular nonpension debt and incur costs of financial distress. Furthermore, cash drains from required contributions depress capital investment at the firm level (Rauh (2006)). The system of required contributions thus creates an incentive to limit risk taking in pension plans, as large mandatory contributions may affect the ability to invest in attractive projects. This has been the case for much of the U.S. airline, automobile, and steel industries. This influence against risk taking in pension funds has been ignored by previous literature which instead has emphasized the tax benefits of funding with debt (Black (1980), Tepper (1981)) as a countervailing force against the moral hazard associated with pension investment (Sweeting (2005), Campbell and Viceira (2005)).

There are therefore theoretical reasons why pension risk might optimally increase as the sponsoring firm approaches financial distress, and theoretical reasons why it might optimally decrease. The results in this paper suggest that risk management incentives to avoid costly financial distress dominate risk shifting on average in pension fund investing. In a large sample of administrative data covering primarily small to medium sized DB plans during 1988-2003, the better funded pension plans which should have less incentive to engage in risk shifting — in fact invest in riskier assets than the more poorly funded plans which would be the typical risk shifting candidates. This is also the case within plans over time. After the funding status of a given pension plan improves, the plan assets tend to be invested more in equities; after the funding status deteriorates the plan assets tends to be invested more in safe assets such as government debt and cash.

Analysis conducted using survey data on pension fund asset allocation for a smaller sample of the largest publicly traded DB pension sponsors from 1997-2004 corroborates the importance of risk management. Firms with better credit ratings and therefore lower expected costs of financial distress take more risk in pension plans than firms which have higher expected costs of financial distress. The allocation to safe assets rises and the allocation to risky assets declines within a given firm over time if its credit rating deteriorates, and vice versa if its credit rating improves. However, there is no evidence that firms dynamically tailor pension investments to correlate with their own investment opportunities (as 
would be predicted by Froot, Scharfstein and Stein (1993)). For example, there is zero within-year correlation between the return on pension assets and the return on operating assets within this sample.

A related investigation estimates probabilities of a PBGC bankruptcy termination or a corporate bankruptcy filing in the plan-level and firm-level samples and considers the relation between pension fund asset allocation and the estimated probability of default. In both contexts, the percentage of DB assets allocated to equity declines as the probability of bankruptcy increases, while the percentage allocated to safer assets rises. This is consistent with risk management dominating risk shifting considerations, even as firms draw closer to bankruptcy.

In both the plan-level and firm-level samples I also find that asset allocation is correlated with short-term lagged investment returns, with higher returns preceding higher equity allocations and lower allocations to debt and cash. While consistent with pure risk management, this finding is also consistent with a number of other frictions including transactions costs of rebalancing, behavioral biases such as investor inertia effects (Thaler (1980), Samuelson and Zeckhauser (1988)), or an excessive focus by managers on the short-term lagged return in assessing the likely risks and returns of investing in risky securities. The results that link asset allocation to the financial health of firms and plans are robust to controlling for lagged investment returns, suggesting that they are not explained by the tendency of shortterm asset allocation to be affected by lagged performance.

As an alternative test of pension risk behavior near bankruptcy, I consider the ex-ante asset allocation of plans that were ultimately terminated in bankruptcy with the PBGC or whose firms eventually filed for bankruptcy. Any evidence that firms and plans which ultimately went bankrupt took more pension risk in the pre-termination period represents an upper bound on the amount of risk shifting that could have occurred, because it also reflects reverse causality: firms more heavily invested in risky securities for reasons unrelated to the insurance incentive are more likely to experience bad draws and pension problems, and consequently to file for bankruptcy. The evidence that firms and plans which ultimately went bankrupt took more pension risk ex ante is weak. A correlation only appears when all observable measures of the probability of financial distress are controlled for. Moreover, plans that 
ultimately terminated had less volatile returns on invested pension fund assets over the entire sample period than the average plan in the sample. The time-series standard deviation of investment returns of assets in plans that ultimately terminate is no greater than that of assets in plans that do not terminate, or than the standard deviation of investment returns on assets held by the PBGC itself.

The restrictions and covenants that other claimants of the firm place on the firm's activities may affect risk-taking behavior by firms in equilibrium, limiting risk shifting and increasing risk management as firms approach technical defaults. Debt agreements, however, do not specify restrictions on pension fund investment policy, even though parties could write contracts that restrict this corporate decision. To the extent that the topic of pensions arises in debt agreements, lenders are typically only prohibiting various kinds of expropriation in the event that the firm defaults on its pensions with the PBGC in bankruptcy. While the existence of covenants might possibly be the mechanism through which firms are financially constrained in the event of general adverse shocks, covenants do not explicitly prevent firms from taking pension risk.

This paper also contributes to the debate on the causes of risk-taking in pension funds. Much of the theoretical literature starts from the demonstration that under certain assumptions, the goal of shareholder maximization is accomplished by investing the pension fund entirely in bonds (Black (1980), Tepper (1981), Bodie (1990)). On average, however, large U.S. pension sponsors invest roughly $60 \%$ of pension fund assets in equity securities. The incentive for risk shifting is the factor that is often pointed to as providing the incentives for equity investment, but the results in this paper suggest that risk shifting is not the primary reason, as the firms for whom this insurance would be the most valuable in general take the least risk.

If risk shifting is not the reason that corporations put money in equities, then what is? While a large fraction of the variation in pension fund asset allocation at the firm level remains unexplained by the empirical analysis, I find a robust, significant, and positive correlation between risk taking and the share of active employees in the pension plan. This result is consistent with Lucas and Zeldes (2006) and Sundaresan and Zapatero (1997), who argue that equity investing in pension funds may hedge against 
increases in pension benefits. This works because pension benefits are tied to real wages, which are positively correlated with stock returns. Thus, if firms are investing optimally then their equity investing may be a hedge against increases in the wage-linked components of benefits. ${ }^{1}$ Another plausible explanation, not tested here, is that the earnings impact of risky pension investment strategies creates an incentive to invest pension assets in more volatile securities (see Bergstresser, Desai, and Rauh (2006)). ${ }^{2}$

The rest of this paper proceeds as follows. Section 1 discusses the incentives for pension fund asset allocation and funding behavior in the context of incentives for risk management and speculation. It also reviews existing literature in these areas. Section 2 describes the data used in this study and presents an example of the pension investment behavior of United Airlines, as well as the asset allocation of a small cross-section of the largest pension sponsors in 2003. Section 3 considers the relation between plan characteristics and asset allocation in plan level data. Section 4 considers the relation between firm characteristics (including those of the firm's pension plans) and asset allocation in firm-level data. Section 5 estimates probabilities of PBGC termination and bankruptcy and examines the relationship between asset allocation and bankruptcy probabilities. Section 6 analyzes the characteristics of DB plans that were ultimately terminated relative to the universe of DB plans. Section 7 concludes.

\section{Pension Investment Incentives, Risk Shifting, and Risk Management}

This section discusses the incentives for pension fund asset allocation and funding behavior in the context of incentives for risk shifting and risk management.

\subsection{Defined Benefit Pension Plans and the Pension Benefit Guaranty Corporation}

In a DB pension plan, the sponsoring firm pledges retirement benefits to employees according to a formula that is generally a function of each employee's age, tenure, and salary. The firm then funds these liabilities with dedicated financial assets, the allocation of which is determined by officers of the corporation often in consultation with investment advisors. Although DB pension plans have been declining in importance relative to defined contribution (DC) plans, assets in private sector domestic DB plans still amounted to $\$ 1.9$ trillion as of the end of 2003 (Buessing and Soto (2006)). 
If a firm enters bankruptcy with insufficient pension assets to cover pension liabilities, the PBGC takes over the pension plan and guarantees that plan recipients receive their annual pensions up to a maximum that is set annually by law ( $\$ 47,659$ in 2006 for employees retiring at age 65 ). Firms pay for this insurance with premiums that depend on the number of covered workers and financial health of the plans, but not the amount of risk taken with financial assets. The PBGC then receives all of the firm's dedicated pension assets, but if it wishes to recover any underfunding the agency in practice has similar priority to that of a general unsecured creditor (Center on Federal Financial Institutions (2004)).

Recent pension fund terminations have strained the financial position of the PBGC. Annual information made available by the PBGC reveals that a surplus of $\$ 9.7$ billion as of the fiscal year ending September 2000 had deteriorated to a deficit of $\$ 22.7$ billion by the end of the 2005 fiscal year (PBGC (2005)). This is by far the worst position in the history of the PBGC, and essentially all of this decline has been due to losses from complete and probable terminations (Coronado and Liang (2005)). The PBGC has projected a "reasonably possible" exposure of as large as \$108 billion, representing the estimated amount of unfunded vested benefits at firms with a large probability of default. Such deficits come about as a combined result of poor investment performance and low levels of voluntary contributions. The recent termination of the pension plans of United Airlines was the largest termination event in history, with the PBGC assuming \$6.6 billion of United's \$9.8 billion in unfunded liabilities.

\subsection{Pension Investment Incentives in Previous Literature}

Sharpe (1976) and Treynor (1977) first demonstrated that the contract between plan sponsors and pension beneficiaries (or guarantors) is essentially a put option exercisable in bankruptcy and written on the assets of the pension plan with a strike price equal to the value pension liabilities. This was the case even before the formation of the PBGC in 1974, as in bankruptcy the pension beneficiaries were generally bound to accept whatever reduced pensions could be provided to them by the bankrupt firm using the

firm's pension assets. The introduction of the PBGC exacerbated the moral hazard problem in that it gave the pension beneficiaries a muted incentive to monitor the corporation's pension investment policy. The 
PBGC exerts little control over the corporation when it is a going concern, outside of the contribution requirements and the collection of the insurance premiums which are not risk-based.

Under this arrangement, if asset values rise then the firm's need to fund the pension fund with cash is reduced. If pension fund asset values fall, and the firm enters bankruptcy, then the firm is relieved of its pension liability. The more volatile the pension assets, the more valuable this pension put option. Harrison and Sharpe (1983) derive optimal funding and asset allocation rules and show that under some conditions the put option may be valuable enough to lead to a corner solution in which the firm makes minimal contributions to the pension fund and invests any assets completely in equity securities. A number of papers have calculated explicit values for the PBGC put option, either from the point of view of the individual company (Marcus (1987), Pennacchi and Lewis (1994)) or from the perspective of the PBGC (Boyce and Ippolito (2002)). Kroszner (2005) and others have compared the current condition of the PBGC to the situation of the Federal Savings and Loan Insurance Corporation (FSLIC) on the eve of the savings and loan crisis of the 1980s.

These incentives are a manifestation of the classic risk-shifting incentives originally discussed in Jensen and Meckling (1976) and Myers (1977). When debt is underwater in some states, investments or transactions that increase the volatility of cash flows also increase the value to shareholders of their call option on the firm's assets. Parrino and Weisbach (1999) examine the likely importance of these kinds of stockholder-bondholder conflicts using numerical techniques. However, empirical evidence of risk shifting has been thin. Andrade and Kaplan (1998) find no evidence that the financially distressed firms they study engage in risk shifting. Kroszner and Strahan (1996) show that while insolvent savings and loan institutions (S\&Ls) appear to have increased dividends to shareholders, such payouts are generally positively correlated with the financial health of the institution.

Shareholder-creditor agency problems such as risk shifting arise from flexibility of ex post actions, i.e. after debt is in place, and when the firm's risk strategy cannot be contracted upon ex ante (Leland (1998)). This seems an appropriate assumption about risk-taking in pension funds, as firms cannot commit to pension beneficiaries or the PBGC not to underfund the pension and take risks with the 
assets. While creditors could theoretically demand that restrictions on pension fund investment be written into financial covenants, in practice this seems not to happen, perhaps because the PBGC faces such a low priority in the event of a default.

Other theoretical analysis has demonstrated that in the absence of pension insurance, firms may have strong incentives to fully fund the liabilities of the pension plan and invest entirely in fixed income securities with the same duration as the liabilities owed to beneficiaries. If pension fund assets perform well, the firm will be under pressure from employees to increase benefits (Bulow and Scholes (1983), Bodie (1990)). This likelihood is increased by the fact that once a firm has contributed to a pension plan, it cannot withdraw the assets except in order pay beneficiaries or in certain rare circumstances. ${ }^{3}$ Therefore, if the PBGC insurance were not valuable, shareholders would own more of the deficit created by poor asset performance than the surplus created by good performance, and in fact would have written a put option on the value of the assets in the pension fund, rather than owning such a put option. There are also strong tax arguments for holding more heavily taxed assets within the pension fund. Firms that hold equity in pension funds and bond-like assets outside the pension fund are acting in a tax inefficient manner. They could undertake tax arbitrage transactions that increase shareholder value by reducing equity exposure within the pension fund (Black (1980) and Tepper (1981)).

Given that firms invest pension funds so heavily in risky assets, there must be benefits to this behavior that are outside of the above models. The PBGC is often considered the primary driver of risktaking in pension funds, a claim which I evaluate in this paper, and for which I find little evidence. There are numerous alternative hypotheses that may explain why firms invest in equity at all in pension funds.

First, the firm may desire to offer pension beneficiaries the upside to good performance in pension assets (Sweeting (2005)) or access to alternative securities that may not be available to individual investors (Campbell and Viceira (2005)). Second, as hypothesized by Gold (2005) and demonstrated by Bergstresser, Desai, and Rauh (2006), firms may wish to maximize the short-term earnings impact of selecting an equity investment strategy that allows for the assumption of a high rate of return on pension assets. Third, as in Lucas and Zeldes (2006) and Sundaresan and Zapatero (1997), firms may invest in 
equity to hedge against increases in projected benefits owed to employees; these projected benefits are a function of real wages which are likely correlated with the stock market.

Fourth, some observers have proposed that decisions about pension funds are made in a vacuum with respect to the rest of the firm's operations. This last explanation is denied in conversations with industry insiders as well as in voluntary disclosures about the pension investment governance process (see for example Lucent Retirees Organization (2003)). The board of the corporation and committees of its managers are responsible for setting pension fund investment policy and appointing or hiring investment managers to execute it. Many firms have entire internal divisions responsible for investing pension assets (Denmark (2006)). A lack of consideration of corporate objectives in pension fund investing is nonetheless a possibility at poorly managed firms.

This study focuses primarily on asset allocation within pension plans as a function of other characteristics of the plans and their sponsors. The study of the funding decision is also of interest but is characterized by the fact that firm actions are constrained by law. Firms must fund pension plans up to legally mandated statutory levels, and since 1987 have only received tax deductions for contributions to underfunded plans, using a strict definition. Furthermore, Rauh (2006) shows that most underfunded pension plans contribute at the statutory minimum amount, although there are examples of large voluntary contributions (e.g. General Motors in 2003).

In untabulated specifications, I also examine contribution behavior, but the results do not contribute greatly to understanding risk taking in pension funds. Firms contributions to pension plans are greatest when the plans are more underfunded, consistent with the fact that this is when mandatory contribution requirements are the strongest. Firms also make larger contributions when they have more cash on hand and more cash flow. The unrestricted nature of asset allocation in pension funds makes it a more fruitful area for consideration.

There have been a number of previous empirical studies of pension funding and asset allocation that examine these incentives, with generally conflicting conclusions. These studies include Friedman (1983) which uses a cross-section of approximately 8,000 plans from 1977; Bodie, Mørck, and Taggart 
(1985) and Bodie, Mørck, and Taggart (1987), which draw on a dataset of 939 firms from 1980; Petersen (1996) which uses IRS 5500 data from years 1988-1990; Hsieh, Chen, and Ferris (1994) which uses a cross-sectional dataset of 176 firms in 1989, and Coronado and Liang (2005) which uses a cross-section of 363 observations from 2002. These studies have reached conflicting conclusions about both the degree integration of corporate pension policy with real corporate decisions and the direction of the effects. For example, Bodie, Mørck, and Taggart (1987) find a negative correlation between risk taking and funding, consistent with risk shifting, whereas Petersen (1996) finds a positive correlation. The primary obstacle has been that until now a sufficient panel dataset has never been compiled to study these issues in a way that allows the consideration of both cross-sectional relations and relations within firms and plans over time.

The results in this paper contrast with the findings of Cocco and Volpin (2007), who find a positive relationship between firm leverage and allocation to risky assets among a sample of 90 U.K. firms when the pension trustees are aligned with shareholder interests. This is probably due to the fact that the institutions governing the U.K. system are different from those of the U.S. system. In particular, the system of mandatory contributions may not be as punishing if the pension gets underfunded, allowing firms in the U.K. system more leeway to take risk.

\subsection{Risk Management and Other Constraints on Risk Shifting in Pension Funds}

The literature has identified a number factors that limit the risk-shifting conflict of interest between shareholders and creditors (see Harris and Raviv (1991) for a review). For pension fund investing, the incentive to manage cash flow risk is one such factor. As emphasized in a general context by Leland (1998), there is a tension between any factor that makes risk management more valuable and any incentives for risk shifting. Poor realizations from pension fund investing require the firm to make cash contributions to pension funds (Rauh (2006)), which in turn create several problems for the firm.

First, mandatory contributions may contribute to the firm incurring costs of financial distress if the cash drain causes a default on the firm's nonpension debt. Mayers and Smith (1982) and Smith and Stulz (1985) formalize the idea that if financial distress is costly then risk management can increase 
shareholder value by reducing the probability of financial distress. Indeed, one prediction of these models is that as firms get closer to financial distress they should take fewer risks that might cause the costs of financial distress to be incurred.

Second, mandatory contributions may force financially constrained firms to forgo investment projects. Several models link the benefits of risk management to debt overhang (Mayers and Smith (1987)), and to the covariances between the stochastic process underlying the risk and the firm's investment opportunities. As in Froot, Scharfstein and Stein (1993), firms that are financially constrained can create value by minimizing the risks of ending up in the state of the world where they have profitable investment opportunities that need to be funded from internal funds, which are depleted because of the risk outcome. Building on this argument, Acharya, Almeida and Campello (2007) develop a relationship between hedging demand and corporate cash and debt policies. Almeida, Campello and Weisbach (2006) explicitly model the impact that future financing costs might have on financial and investment policy, particularly with respect to incentives for limiting risk-taking behavior. ${ }^{4}$ Translating these arguments into the pension context, the higher the probability that the firm suffers a pension loss but still survives, the greater are the risk management incentives. Indeed, Petersen (1994) has looked at the choice of pension plan type (DB versus DC) as a risk management strategy.

According to Almeida and Philippon (2007), the 5-year historical default probability for BBB, B, and $\mathrm{B}$ rated firms are $1.95 \%, 11.42 \%$, and $31.00 \%$ respectively. Both the risk-shifting incentive and the risk-management incentive to avoid costly financial distress would therefore be expected to increase as credit ratings decline. The risk-management incentive to avoid the state where there are high mandatory contributions but the firm survives might be expected to be stronger for investment grade firms when default probabilities are low. On the other hand, investment grade firms may have more easy access to external finance, and therefore they may have less incentive to be concerned about financial constraints.

Another often hypothesized factor that mitigates risk shifting is the existence of explicit covenants on firm behavior in loan agreements (Lehn and Poulsen (1991)). However, such agreements do not specify restrictions on pension fund investment policy, even though pension fund asset allocation 
is a contractible choice. Furthermore, as evidenced by the variety of risky and alternative assets held by pension funds, ERISA is also extremely permissive.

In the case of pension funding and investment policy, the tension between risk shifting and risk management is very apparent. If the firm goes bankrupt, the unfunded liability is low in priority. This creates an incentive for the firm to take risks with the assets that back that liability during the period before a possible bankruptcy. On the other hand, if the firm survives and has to make large statutory contributions to its pension plan, it will have lost all of the potential benefits from risk management. In particular, it may face financial distress, and it may lose the opportunity to undertake profitable investment projects This creates an incentive for the firm to limit pension fund risk ex ante.

The empirical predictions that emerge from this analysis are as follows. If risk shifting is an important determinant of risk taking in pension funds, then one should observe plans of firms near financial distress taking large risks. Within plans over time and within firms over time, risk should increase as funding and financial condition deteriorate. If risk management is an important constraint on risk taking in pension funds, then risk taking should be smaller as funding and financial condition deteriorate.

\section{Data and Summary Statistics}

I use two sources of asset allocation information in this paper: 1.) the electronic IRS 5500 filings from the Department of Labor on a large sample of small to medium sized plans and 2.) the survey-based data on the largest corporate pension sponsors from Pensions and Investments matched to Compustat. These data are used in two different sets of analyses, as their coverage for asset allocation generally does not overlap, for reasons described below.

\subsection{IRS 5500 Filings and the United Airlines Pension Plan}

The most detailed pension allocation data are contained in the IRS 5500 filings. All sponsors of pension plans with more than 100 employees must file the IRS form 5500 on an annual basis. The U.S. Department of Labor (DOL) is entrusted with keeping the information on file and providing it to the public upon request. A full filing consists of many schedules, plus what generally amounts to dozens of 
pages of attachments. The DOL makes all of the schedules available electronically for years after 1984, usually with a 2-3 year lag. The attachments, however, are only available in hard copy. The latest year for which all the data are available is 2003 . The electronic data from 1984-1987 contain only a subset of the requisite variables for this study and so I do not use those years. The data include non-profit organizations and unions but primarily consist of corporate sponsors.

Information on asset allocation may appear in two parts of the filing. First, Schedule H, which is part of the electronic dataset, contains a breakdown of asset allocation into standardized categories. However, on this form, firms may classify assets as belonging to opaque categories that are not informative as to their risk. So while firms can declare assets as being in corporate stock or government bonds, they can also assign those assets to common or collective trusts, pooled separate accounts, master trusts, 103-12 investment entities, and registered investment companies. It is generally larger pension sponsors that avail themselves of these vehicles. In order to determine the full asset allocation of these opaque categories, one must look at the hard-copy attachments.

Table 1 shows a summary of information that can be gleaned from the filings of UAL Corporation, the parent company of United Airlines. UAL Corporation filed for Chapter 11 bankruptcy in 2002 and terminated its pension plans with the PBGC in 2005 after lengthy bankruptcy proceedings. Covering the period 1999-2004, this table shows the allocation of the United Airlines pension trust to four asset classes: common and preferred equities, corporate and government debt, private equity, and cash and short-term instruments. This trust contains the assets backing the pensions of the entire domestic workforce of United Airlines. The first column of the table shows the deep decline in and then partial recovery of available pension assets over time. Variation in this quantity is due to changes in the market value of the assets as well as the level of contributions net of benefit payments. The share of assets allocated to risky investments such as stock and private equity did not rise substantially right before UAL's bankruptcy filing, with assets allocated to common and preferred equities declining from $66.8 \%$ in 1999 to $59.7 \%$ in 2001 . The percentage allocation to private equity rose from $2.2 \%$ to $4.4 \%$ over this period, but the percentage allocation to the safer asset classes (debt and cash) rose more substantially. 
Allocation to risky assets did rise somewhat during the bankruptcy proceedings, during which time the managers of UAL Corporation still controlled the pension assets.

These patterns may be partially explained by passive or inertial investing in which asset classes which have increased in value end up with higher asset allocation shares, or some direct cost of rebalancing. The final two columns of Table 1 show the predicted share if there is no rebalancing under different assumptions about the reinvestment of dividends and interest payments. The allocation shares generally move in direction that would be predicted if there were no rebalancing, though they do not move as far. For example, the allocation to equities declined from $59.7 \%$ to $56.9 \%$ between 2001 and 2002, whereas if there had been no rebalancing and dividends and interest payments had been reinvested, they would have been predicted to decline to $54.4 \%$.

This detail of information cannot be collected for a large sample of plans, so the large-sample analysis in this paper that draws on the IRS 5500 filings is restricted to those plans whose asset allocation can be obtained from the electronic data. For this analysis I examine asset allocation as revealed only by plans for which these opaque assets are less than five percent of the total, which is roughly $40 \%$ of the sample. This sample selection skews the sample towards small to medium sized plans, which are less likely to use these investment vehicles. The mean size of plans that survive this filter is $\$ 48$ million, compared with $\$ 84$ million of the entire sample. Furthermore, consistent definitions of pension liabilities are only available after 1990, so I further restrict the sample to cover the years 1990-2003.

I identify plans which terminated in bankruptcy by constructing a web crawler to extract the reports of terminated plans on the PBGC website. ${ }^{5}$ This procedure uncovers 3,574 plans that were terminated between 1974 and the present, which compares to a total count of 3,585 from the PBGC annual report (PBGC (2005)). Of these plans, 1,130 could be matched to plans between 1988 and 2003 in the IRS 5500 database, compared to a total count of 1,822 for years 1988-2003 in the PBGC annual report (PBGC (2005)). The loss of 692 observations here reflects the restriction of the IRS 5500 dataset to plans with more than 100 employees. 
The effects of the sample selection and the summary statistics for the main variables used in this analysis are detailed in Tables 2a and 2b. Table 2a shows summary statistics for the full 1988-2003 sample. The only sample restrictions are that the observation had to be a DB plan with greater than 100 employees, with information on beginning-of-year plan assets (which also had to be nonzero), contributions, and investment income. PBGC terminations from the termination database were then merged onto this data by EIN and plan number. This procedure added some observations back to the dataset since often the year of the termination was after the plan's final complete IRS 5500 filing. Table $2 \mathrm{~b}$ shows summary statistics for the sample used in the analysis. It restricts the sample to only those observations which are in 1990-2003 and for which opaque assets are less than 5\% of total pension assets.

The full sample of plan-level data consists of 214,015 observations on 33,144 unique plans (as identified by unique EIN and plan number combinations) and 23,456 unique employers (as identified by unique EINs). The mean pension plan observation in the sample has asset value of $\$ 84.46$ million as of the beginning of the plan year and the median has asset value of $\$ 6.53$ million, so size is highly skew in this sample with some larger firms having a large impact on the sample moments. Investment income from these firms is similarly skewed. The largest dollar value return on invested assets was $\$ 8.7$ billion for General Motors primary pension plan in 1999, and the most negative return on invested assets was $-\$ 5.5$ billion for the same pension plan in 2001 .

Table 2a also provides ratios in percentage terms for plan terminations, funding status, and investment returns. Investment returns are calculated as investment income divided by beginning of year assets and therefore incorporate the assumption that contributions are not made until the end of the year. Investment returns of less than $-80 \%$ or greater than $500 \%$ are replaced as missing, which only affects a total of 32 observations. The remaining ratio variables are winsorized at the $1 \%$ level to avoid outliers. The mean value of contributions is $9.30 \%$ of beginning-of-year assets..

As revealed by plans in this sample with less than $5 \%$ of assets in opaque trusts, plans held an average of roughly $30.6 \%$ of assets in government debt and cash, $25.5 \%$ of assets in corporate equity, and $23.2 \%$ of assets in insurance company general accounts. In insurance company account arrangements, the 
insurance company provides an annuity that pays the pension benefits and keeps plan assets in their general pool of funds. This is comparatively a very safe arrangement for the pension sponsor, as the risk has been transferred to the insurance company which invests only in high grade securities. Only if the insurer defaults on its contracts is the pension sponsor potentially exposed to the risk of its beneficiaries not receiving their pension annuities. Alternative statistics are also shown in the table in which insurance company general account assets are excluded from the denominator.

The corporate equity calculation includes the own stock of the employer, which on average is present only in a trace amount $(0.3 \%$ at the mean), due to statutory restrictions and practical limitations posed by the firm's fiduciary responsibilities to beneficiaries. It does not include private equity.

Figure 1 illustrates the development of the mean asset allocation in the major asset classes over the time period of the sample. The top graph includes insurance arrangements and the bottom graph excludes them. In both cases, the clear pattern emerges that allocation to stocks has increased dramatically, on the order of $25 \%$ between 1988-2003. Allocation to cash and government debt have declined by a similar amount. If anything over this time period, risk management incentives should have increased as funding rules were made somewhat stricter by the Retirement Protection Act of 1994. Risk shifting incentives may have been stronger or weaker at various times depending on the financial condition of firms. This figure is most consistent with the idea that firms moved assets towards equity in order to keep the expected return on pension assets constant over a period of falling bond yields. As yields declined over this time period, there were two ways that firms could maintain a constant expected return on pension plan assets: either they could increase allocation to equity relative to bonds, or they could shift allocations away from bonds towards stocks.

Table $2 \mathrm{~b}$ shows the summary statistics when the sample is restricted to the observations that can be used in the estimation (1990-2003 and less than 5\% opaque investment assets). As discussed above, the mean size of the pension plan declines from $\$ 84$ million to $\$ 48$ million; the median declines from $\$ 6.53$ million to $\$ 6.24$ million. Sample firms have roughly half the average level of investment income 
and contributions as firms in the IRS 5500 universe. Roughly the same proportion of observations represents a bankruptcy termination $(0.25$ percent versus 0.27 percent $)$.

\subsection{Pensions and Investments Survey Data and the Largest U.S. Pension Sponsors}

Large, publicly-traded companies, such as those in Compustat, are more likely to have a large proportion of assets in opaque trusts. Furthermore, accurate matching of the IRS 5500 database to Compustat was only feasible before 1998 (see Rauh (2006)) when the IRS 5500 forms contained a CUSIP field, in addition to an EIN and a company name. A corporate entity with subsidiaries consists of companies with several different names and EINs. For these reasons, focusing on the matchable nonopaque sample between 1990 and 1998 yields an insufficient sample.

In this study I therefore also perform separate analysis using the Pensions and Investments survey matched to Compustat for 1997-2004. The newspaper Pensions and Investments annually profiles the 1,000 pension sponsors from all sectors of the economy (public and private) with the largest amount of assets. The newspaper surveys the sponsors with regard to the asset allocation of their pension funds as of September $30^{\text {th }}$ of the year in question. I match the results of this survey to Compustat by company name, first using a name-matching algorithm and then hand-matching as many unmatched companies as possible.

Table 3 shows information obtained from Pensions and Investments for a sub-sample of 13 large DB pension sponsors in the U.S. in 2003, and compares it to the information on these sponsors that was able to be obtained from the IRS 5500 attachments. The companies consist of 9 of the 10 largest pension sponsors, plus major airlines that filed for bankruptcy. ${ }^{6}$ The two sources are not taken at exactly comparable time periods, as the typical plan year ends in December whereas the survey is taken as of September. However, correlation coefficients between the two sources are quite high. The correlation coefficient between the percent in stocks according to the IRS 5500s and the percent in stocks according to Pensions and Investments is 0.88 . For the percent in bonds plus cash it is 0.85 , for private equity it is 0.94 , and for real estate it is 0.86 . 
Table 3 also compares these two sources to another source of information on pension asset allocation, the disclosures recently available in SEC 10-K filings. Since the FASB revision of SFAS 132 in 2003, firms have been required to present such information, so that for most firms an asset allocation breakdown is available from 10-K filings for fiscal years ending 2002-2004. However, the asset allocation categories are coarse, as shown in the table. Correlation coefficients between the cross-sections of stock and bond allocations from this source and the other two sources run from 0.80 to 0.96 .

Importantly, a cursory analysis of Table 3 does not suggest that more financially troubled firms choose to take more risk in their pension plans as revealed by the allocation to the different classes of investment. Based on the Pensions and Investments data, the highest allocation to stocks plus private equity is $71.7 \%(=52.6 \%+12.2 \%)$ at Verizon, which has an $\mathrm{A}+\mathrm{S} \& \mathrm{P}$ credit rating. The lowest allocation excluding firms that were already in bankruptcy in 2003 (United Airlines and U.S. Airways) is General Motors at 57\%, and this company has a BBB rating. Of the companies in Chapter 11 in 2003, United Airlines allocated $64 \%$ of its pension fund to stocks and private equity, whereas U.S. Airways allocated only $42 \%$.

In order to perform statistical analysis with credit ratings, it is necessary to have a numerical scale for the S\&P credit rating. I scale the Compustat credit rating variable so that values are between zero and one, with higher values implying better credit ratings. If the firm has an AAA credit rating with S\&P then the credit rating variable equals 0.929 , if the firm has a $\mathrm{D}$ rating then the credit rating variable has a value of 0.036 , and each of the 28 rating steps in between raises the credit rating variable by 0.036 (or $1 / 28$ ).

For the observations in Table 3, the correlation coefficient between this credit rating variable and the percentage allocated to stock and private equity is 0.44 including all of the companies in the table, and 0.22 including only the ones not in Chapter 11 as of 2003. This implies that if anything the correlation runs in the direction of worse-rated companies having lower allocations to equity and better-rated companies having higher allocations to equity. In other words, this first analysis is more suggestive of risk management than risk shifting, but clearly this is only suggestive. 
Table 4 shows summary statistics for the key variables from the portion of the Pensions and Investments survey database that was able to be matched to Compustat. The final dataset contains 2,186 total observations on 438 unique firms. Observations for which asset allocation shares were missing due to survey non-response or did not add up to one were dropped, which led to a loss of 690 observations. Only observations for which Compustat data was available for all the variables in the table were retained. Observations with no credit rating receive a value of zero for that data item, but there is also an indicator for observations with no credit rating, which equals one for $8.7 \%$ of sample observations. It should be emphasized that this paper's sample is far from representative of public firms. In the Compustat universe, roughly one-quarter of firms have a bond rating.

Pension assets are measured as U.S. pension assets at the end of the year as collected from SEC 10-K filings. Where this information is unavailable, global pension assets from Compustat (data287+dat296) are used. Pension liabilities are measured as the U.S. projected benefit obligation at the end of the year, again as collected from 10-K filings where possible, otherwise using Compustat (data286+data294). The pension funding status is the pension funding surplus or deficit (pension assets minus pension liabilities) scaled by pension liabilities. Firms in the sample have a mean of $\$ 3.5$ billion dollars in pension assets and have pension liabilities that at the mean amount to $20 \%$ of the firm's operating assets. These observations are at the mean 5.2\% overfunded, at the median roughly fully funded, and the funding status has a standard deviation of $30 \%$.

Table 4 also shows summary statistics for other control variables from Compustat, including pension related variables. These are reported on a global basis. Benefits measures include projections of pension benefits that will be owed to employees as their wages and years of service increase over time. Altman's Z-Score is (3.3*EBIT / Operating Assets) + (Sales / Operating Assets) + 1.4*(Retained Earnings / Operating Assets $)+1.2 *($ Net Working Capital / Operating Assets). The ratio of cash flow to assets is cash flow (net income + depreciation and amortization + pension expense $=$ data $14+$ data $18+$ data43) divided by total assets (data6). 
Allocation to debt and cash averaged $30.41 \%$ over the sample period, and allocation to equity averaged $63.20 \%$. One drawback of the survey is that respondents are not asked to distinguish government and corporate bonds. Allocation to private equity and real estate averaged $3.54 \%$, while all other assets accounted for $2.85 \%$ at the mean. Insurance company arrangements do not typically play a large role in the investment of pension assets for the large publicly traded companies covered by the Pensions and Investment survey, and these arrangements are aggregated into the "other" category.

\section{Plan Characteristics, Firm Characteristics and Asset Allocation}

One method of testing the risk shifting hypothesis against the risk management hypothesis is to examine the observable components of risk exposure with respect to characteristics of the sponsoring plan. In this section I examine this relation in the IRS 5500 plan level data.

At the plan level, the main explanatory variable of interest is the funding status of the pension plan. The level of assets to fund a given liability is the cumulative result of all past investment returns, as well as past decisions about how much to contribute to the plan net of benefits paid out. Plans that are well-funded are likely to reflect financially healthy sponsors. Furthermore, the more underfunded the pension plan, the further in the money is the put option for the pension sponsor. Under the risk shifting hypothesis, therefore, better funded plans should take less investment risk, whereas under the risk management hypothesis they would take more risk.

Table 5 shows a series of 8 regressions ( 4 in each panel) documenting the relationship between the percentage of the pension fund invested in equity and plan characteristics. The first two columns are pooled regressions, including year effects but no plan fixed effects. The last two columns include both year and plan fixed effects. The dependent variables are scaled in terms of percentage points. The second and fourth columns contain controls for the one year lag of investment returns to examine how past investment returns may affect investment allocation shares.

The regressions in the first two columns reveal that in the cross-section, plans that are better funded invest more in equity securities. A 10 percentage point higher funding status is correlated with 0.545-0.676 percentage points greater allocation to equity. Within firms over time, a 10 percentage point 
higher funding status is correlated with an 0.163-0.229 percentage point greater allocation to equity, as revealed by the last two columns of the top panel. The second panel of Table 5 shows similar but inverse patterns for the relation between funding status and allocation to the safe asset classes. If pension funding deteriorates within a firm over time, the percent of the pension fund invested in safe securities tends to increase.

All specifications contain linear and log controls for the size of pension assets in order to absorb size effects. The size effects themselves are generally non-monotonic, with the positive log effect dominating at values of up to $\$ 3.2$ billion. Based on coefficients of -1.5 for assets in billions of dollars and 4.8 for the natural $\log$ of assets, an additional $\$ 100$ million of assets at mean characteristics $(\$ 45$ million in assets) is correlated with 5.47 percentage points higher equity exposure (.15 percentage points lower equity exposure through the linear term and 5.62 percentage points higher equity exposure through the log term). The negative size effect that dominates at higher values is of a relatively small magnitude, with a $\$ 50$ billion dollar fund predicted to have a $1.4 \%$ lower allocation to equity than a $\$ 3$ billion fund.

Controls are also included in all specifications for the active share of employees. The coefficient in the pooled equity regressions is 3.76-4.32 and is highly statistically significant. This implies that firms with a 10 percentage point larger share of active employees have roughly 0.4 percentage point higher allocations to equity. The coefficient in the within-firm regressions is between 3.1 and 3.4. These results suggest that as the active share decreases and the liabilities on average must be met sooner, the firm takes less pension investment risk. Note that since new employees are increasingly not brought in on DB plans, the active share has been decreasing over time at most firms.

The controls for lagged investment returns in the second and fourth columns of the table show that the percentage of assets invested in each category does appear to vary in statistically significant ways with the lagged investment return. In the pooled specification, a 10 percent higher investment return leads to a 2.9 percentage point higher allocation to equity; within firms over time the effect is 0.9 percentage points. The percentage of the pension fund invested in safe assets appears to decline accordingly when lagged investment returns are high. Most of the variation in investment returns is likely 
caused by fluctuations in the values of the most volatile assets. The significance of lagged investment returns in explaining asset allocation might represent the fact that when investment returns are bad, pensions become less funded and then the need to manage risk becomes greater. Alternatively, it reflects a behavioral inertia effect in investing, a cost of rebalancing, or an excessive focus by managers on the one-year lagged return in assessing the likely risks and returns of investing in risky securities. The effects of the other variables are still strong even in the presence of these controls.

Figure 2 shows the relationship between the decile of the funding status and the percent of total assets invested in equities versus government debt and cash. The top graph illustrates the coefficient results from two pooled regressions of asset allocation (one regression for equity, the other for debt, cash, and insurance) on funding deciles with year controls. The relation between funding status and percent of total assets invested in stocks is monotonically increasing, whereas the relationship between funding status and the percent invested in government debt, cash and insurance is monotonically decreasing. The omitted category in both graphs is the lowest funding decile. Therefore, the top graph shows that plans in the second (i.e. second-worst) decile of funding have allocations to stocks that are 4 percentage points greater than those in the first (i.e. worst) decile of funding in the same year. Plans in the top (i.e. best) decile of funding have allocations to equity that are 15 percentage points greater than plans in the worst funding decile in the same year. The allocation to government debt, cash, and insurance shows a roughly inverse response. The lower graphs shows the same coefficients within firms over time, controlling for plan fixed effects. A similar relation holds, though of magnitudes that are roughly only $25 \%$ as large as those in the pooled specification.

Table 6 shows the specifications in Table 5, but considers only plans with assets not $100 \%$ invested in insurance company general accounts and redefines the dependent variables to be the percent of all non-insurance pension assets held in the given asset class. The dependent variable in the top panel is therefore the percent of the plan's non-insurance pension assets held in equity and the bottom is the percent of the plan's non-insurance pension asset held in government debt and cash. The results are 
similar to the results in Table 5. Funding status effects on pension fund asset allocation are generally even stronger.

The relationships between pension fund asset allocation and plan characteristics can be summarized as follows. Plans with worse funding in general take less investment risk than plans with better funding, even controlling for both calendar year effects and firm fixed effects. This effect is of a similar magnitude to Petersen (1996). Moreover, plans whose employees are on average farther away from retirement take greater risk in the pension plan. Therefore, pension plans take fewer risks when those risks could be most costly to the firm's operations in the future.

\section{Firm Characteristics and Asset Allocation}

This section considers between firm characteristics and risk-taking in pension plans. For reasons explained in Section 2, I address this question with a different dataset, the Pensions and Investments data on pension fund asset allocation. In particular, I focus on the relationship between firm credit ratings and asset allocation, as the credit rating is arguably the best available measure of the firm's financial strength and the likelihood of defaulting on debt agreements.

Table 7 shows the results of regressions of pension fund investment strategies on firm characteristics in pooled specifications, i.e. without individual firm effects. The left panel presents regressions on the percentage of assets invested in debt and cash, and the right panel presents regressions on the percentage of assets invested in equity. Within each panel there are three different specifications with different sets of control variables. The first column contains only controls for the size of the firm's operating assets and pension assets. The second column contains additional controls for the Z-Score measure of bankruptcy probability and the standard deviation of operating cash flow. The final column also includes controls for the size of the pension obligation relative to operating assets, and to the pension funding status (the pension surplus or deficit scaled by pension assets).

The results in Table 7 demonstrate that S\&P credit ratings are positively correlated with the share of pension fund assets invested in equity, and negatively correlated with the percentage of the pension fund assets invested in debt and cash. The coefficients on the S\&P credit rating represent the 
approximately the difference in allocation shares between an observation with the worst credit rating and the best credit rating. This difference is -5 to -6 percentage points for debt and +8 to +10 percentage points for equity. This result is statistically significant in all but one of the specifications. The results reveal that firms with better credit ratings invest their pension funds in more risky assets.

The credit rating result is the opposite of the expected prediction if risk-shifting incentives were driving pension fund asset allocation, and is much more consistent with the risk management hypothesis. Furthermore, the positive correlation between credit rating and asset allocation is the opposite of what would be expected if credit ratings were being set endogenously to reflect the risk that firms were taking in their pension funds. If anything, rating agencies should tend to give lower ratings to firms with riskier positions for a given level of funding.

Table 7 indicates that the $8.7 \%$ of the sample with no credit rating are likely to have somewhat higher allocations to equity than firms with a credit rating. This result is difficult to interpret given that some of these firms are high-quality firms that have no need of accessing the credit markets - especially those without a credit rating for the entire sample period, or young firms which gain credit ratings during the sample period. Other firms without a credit rating may be distressed firms. I return to this below when I consider the results within firms over time.

The control variables in Table 7 other than size are not statistically significant. The pension funding status coefficients have t-statistics of approximately one in both the debt specification and the equity specification, but the direction of correlation goes in the same direction as in the plan-level regressions. If these coefficients were statistically significant, one would predict that an observation with a 10 percentage point higher pension funding status would have 0.260 percentage points less investment in debt and cash and 0.245 percentage points more investment in equity, again consistent with risk management, not risk shifting.

Table 8 repeats Table 7 but estimates the model using panel data techniques that account for unobserved effects at the firm level. Instead of presenting firm fixed effect specifications, I present random effects specifications because the random effects estimator is more efficient and Hausman tests of 
the consistency of random effects versus fixed effects are highly supportive of the consistency of random effects. The chi-squared test statistics and associated rejection probabilities are shown in the table. Generally one would only reject the consistency of random effects of these statistics were close to zero (less than 0.10 if working with $90 \%$ confidence intervals); they are all 0.80 or above. ${ }^{7}$

Table 8 shows that a very similar relationship between the credit rating and the pension fund asset allocation strategy emerges in the random effects specification, compared to the pooled specifications in Table 7. The conclusions of the cross-sectional analysis therefore also carry over to considering variation in the credit rating within firms over time. The higher the credit rating, the larger the proportion of assets that are invested in riskier securities such as equity and the smaller the proportion of assets that are invested in safe securities such as debt and cash.

The risk management hypothesis predicts that this effect should be stronger for firms with a reasonably high demand for capital. In untabulated results, I divide the sample into groups of firms based on historical 1984-1997 ratios of investment to cash flow and rerun the Table 8 regressions. The results are consistently the largest and strongest in the groups with the highest historical investment to cash flow relation, e.g. above-median firms compared to below-median firms, and top-third firms compared to the other two categories. However, the results are not strong enough to be able to reject the statistical hypothesis that the coefficients in the different groups are of equal magnitude, and the coefficients are not monotonic across the tritiles.

These regressions also suggest that a firm tends to have greater allocation to equity during a year when it lacks a credit rating compared to a year when it has a credit rating. This result is driven by firms that gain credit ratings, not by firms that lose them. There are 38 firms out of 448 that at some point had a credit rating and at some point did not. Of these firms, 12 of them lost credit ratings, while the remainder gained credit ratings for the first time. In untabulated results, I find that removal of the firms that lost credit ratings from the sample regression strengthens the results with this coefficient rising from 4-5 to approximately 9 with very strong statistical significance. Removal of the firms that gained credit ratings from the sample regression reduces the magnitude and destroys the statistical significance. Therefore, the 
finding that a given firm has greater allocation to equity during a year when it lacks a credit rating indicates that firms reduce risk when they get a credit rating for the first time. This could well be because S\&P examines the firm's pension risk before granting a credit rating.

The R-squared of the regressions in Tables 7 and 8 is quite low (0.01-0.02), considerably lower than the R-squared of the plan-level regressions $(0.09-0.12)$. This may be related to the fact that the dependent variable is a survey variable that is measured with error. Furthermore, there is a large amount of persistence in asset allocation choices. The addition of lagged asset allocation to the pooled regressions would increase the R-squared to $45-50 \%$ without affecting the inference about the other explanatory effects. There is in any case a large component of pension fund asset allocation that is not explained by observable characteristics of the firm and its pension assets and liabilities, and may be determined by the investment philosophies and risk attitudes of the sponsors.

In untabulated results, I also examine the correlation between the hedging demand measures proposed by Acharya, Almeida, and Campello (2007) and asset allocation in pension funds. This is done in order to test whether firms select pension investments to correlate with their own investment opportunities (Froot, Scharfstein and Stein (1993)). The measures I consider are the correlation between a firm's Q and its cash flow scaled by assets, the correlation between a firm's Q and the annual return on the S\&P 500, and the correlation between a firm's cash flow scaled by assets and the annual return on the S\&P 500. I also investigate the same correlations using industry median Q instead of a firm's Q. Firms whose own investment opportunities are highly correlated with the market should have a lower hedging demand and be able to take on more risk, since when the stock market (and their pension funding) is down, so is their need for cash to fund profitable investment opportunities. Firms whose own cash flows are highly correlated with the market should have a higher hedging demand and want to take on less risk, since when the stock market (and their pension funding) is down, so is their supply of cash. The results of this investigation were inconclusive, however.

As a further test of the hypothesis that firms optimally hedge pension fund risk, I examine the correlation of the pension investment return with the ratio of cash flow to lagged assets in the presence of 
year fixed effects. On the 2,000 observations for which both of these variables are available, the coefficient in a regression of the pension investment return on the ratio of cash flow to lagged assets is 0.020 with a firm-clustered standard error of 0.023 . While it is certainly the case that years when firms have high cash flow are years when pension funds perform well, there is essentially zero within-year correlation.

Given the plan level results, Table 9 examines another plausible determinant of pension fund asset allocation, the return on pension assets during the fiscal year, in the context of specifications similar to those in Tables 7 and 8 . The sample is 2,008 observations, smaller by 186 observations due to the unavailability of this data item, which was collected from SEC 10-K filings. The left panel and right panel consider the percentage of asset in safe (debt) and risky (equity) securities respectively. Each panel contains three columns: a pooled regression, a fixed effects regression, and a random effects regression. The fixed effects regressions are shown in addition to the random effects regression because the test for the consistency of random effects is somewhat marginal in the left panel (debt and cash), with a probability value of 0.1545 . The test is unequivocal in the right panel (equity).

The first row of Table 9 shows the coefficient on the return on invested pension assets. A 10 percentage point increase in the investment return (roughly one standard deviation) reduces the percentage of assets in debt and cash by 0.772 percentage points in the pooled specification, but by an insignificant amount in the regressions with firm effects. However, a 10 percentage point increase in the investment return raises the percentage of assets invested in equity by over 0.998 percentage points in the pooled specification, and by 0.712 percentage points in the random effects specification. The effect is not statistically significant in the fixed effects regression, but since the random effects regression is consistent and more efficient, the statistical inference should be based on the random effects results.

The remaining rows of Table 9 show the effects of the other variables, which are quite similar to their values in Tables 7 and 8. Controlling for the investment return does not appear to affect the conclusion: pension investment behavior of firms relative to their observable characteristics seems best characterized by the risk management hypothesis. The fact that this result is robust to controlling for 
lagged returns - as well as to the pension characteristics included in Tables 7 and 8 - suggests that it is not driven purely by investor inertia or observationally similar tendencies created by transactions costs. Financially stronger firms still take more risk than financially weaker firms, and allocations to safe assets increase as credit ratings deteriorate.

\section{Bankruptcy Probabilities and Asset Allocation}

In this section, I estimate pension termination and corporate bankruptcy probabilities directly in both the plan level and firm level data. I then non-parametrically examine the equilibrium relationship between the ex ante estimated probability of default and the firm's pension fund asset allocation.

One challenge of this exercise is the definition of the bankruptcy or termination date. As was the case with United Airlines, there may be a lag between the filing of bankruptcy and the termination of the plan with the PBGC. This is much more common when bankruptcies are complicated, as is more likely to be the case with the larger firms in the firm-level analysis than with the firms in the plan-level analysis.

The plan-level data only reveals the date of PBGC termination, not of the bankruptcy filing, which may happen before the termination. In the plan-level analysis I therefore use the date of PBGC termination as the default date of interest, which implicitly assumes that either i.) the date of bankruptcy filing is close to the date of PBGC termination; or ii.) the firm's managers continue to control the asset allocation of the pension fund during Chapter 11. The management of the plan while the firm is in bankruptcy is generally still in the domain of corporate managers, although the PBGC may place unobserved constraints pension fund decisions. There are 1,130 pension terminations in the plan-level database. The binary default variable is defined as 0 up until the last observation before termination.

In the firm-level analysis I use a measure of the date of bankruptcy as the date of default. To identify the bankruptcy date, I use the last data year before the firm was delisted in CRSP, or before the date of bankruptcy filing if there was no identifiable delisting. Using the last year before the bankruptcy filing does not change the inference, nor does redefining the event indicator to be two or three years before the event. There are only 16 corporate bankruptcies of the 448 firms in the sample; these are listed with dates in Appendix Table 1. 
Not every firm that files for bankruptcy terminates its pension plan with the PBGC, as sometimes the plans are sufficiently funded to pay off the pension liability. However, PBGC terminations can only happen in Chapter 11 bankruptcy.

Table 10 shows logit estimates in the plan-level data of the probability that a pension plan will be terminated in financial distress with the PBGC the following year, using the explanatory variables from the investigation in Table 5 and controlling for year effects. Odds ratios are presented in square brackets, in addition to coefficients and standard errors. The left regression includes the funding status linearly and the right regression includes the funding status in deciles. These regressions are estimated in the full IRS 5500 sample described in Table 2 a for which pension liability information is available $(170,080$ observations); the sample is not conditioned on the existence of information about asset allocation.

The results of Table 10 reveal several drivers of pension fund terminations. First, plans that are better funded are considerably less likely to terminate in bankruptcy than firms that are worse funded. This seems logical as overfunded plans do not need to exploit the PBGC put option, even in the case of bankruptcy. However, it is interesting to note that this relation is approximately monotonic when the funding status is separated out by deciles. The odds ratio for a firm in the second funding decile (i.e. second-worst) compared to the worst decile is $65.1 \%$. For the third decile compared to the first it is $60.0 \%$, for the fourth decile it is $42.4 \%$, and so on. So the negative relation between funding and termination probability is not just driven by the difference between underfunded and overfunded plans. Table 10 also shows that plans which have had poor investment returns are more likely to terminate, as are plans with smaller shares of active employees (implying larger shares of retirees).

Figure 3 then examines the relation between the predicted probability of bankruptcy based on the estimates in Table 10 (left column) and the pension fund asset allocation. The top two graphs plot the mean asset allocation (with lines for plus and minus two standard errors) against the probability of bankruptcy. The graphs at the bottom of the page examine the deviation of asset allocation from its within-year mean value against the deviation of termination probability against its within-year mean value. The graphs on the left of the page examine the probability of termination deciles from the least 
likely to terminate to the most likely to terminate. The graphs on the right examine the probability of termination percentiles and focusing only on the top of the distribution, i.e. the $91^{\text {st }}-100^{\text {th }}$ percentile groups. $^{8}$

In all of the graphs the allocation to risky assets is decreasing with the probability of bankruptcy, and the allocation to safe assets is increasing with the probability of bankruptcy. The upper left graph shows that average allocation to equity (as a share of all pension assets including insurance) is approximately $35 \%$ for plans in the least likely termination decile and $24 \%$ for plans in the highest termination probability decile. The upper right graph shows that this value declines to below $20 \%$ in the highest termination probability centile. The lower right graph shows that a plan in the least likely termination decile within a given year has an allocation to equity that is 7 percentage points higher than the average for the plans in that year, and a plan in the most likely termination decile within a given year has an allocation to equity that is more than 10 percentage points lower than the average for the plans in that year.

Logit estimates of bankruptcy probability in the firm-level data are presented in Table 11. Unsurprisingly, worse credit ratings, higher standard deviations of operating cash flow, and lower ratios of cash flow to assets are related to higher probabilities of bankruptcy. These regressions are conducted without year fixed effects as there are a number of years in which there were no bankruptcies. Furthermore, if the goal of the exercise is to generate predicted ex ante probabilities of bankruptcy it is unclear that we want the firm to expect ex ante that the probability of bankruptcy will be higher in a given year. Figure 4 then repeats the analysis of Figure 3 but now on the firm-level sample. The results here are not as conclusive given the much smaller sample and number of bankruptcies in the sample, but are still indicative of downward sloping relationships between risk-taking in pension funds and bankruptcy probabilities.

\section{Ex-Post Analysis}

If moral hazard is an important determinant of pension investment behavior, plans that actually terminated in bankruptcy should have taken on more investment risk in the years preceding the 
termination. However, it is also the case that plans that take greater risk for any reason (not necessarily moral hazard) are more likely to terminate in bankruptcy. A test of whether firms that ultimately went bankrupt took more risk than firms that did not provides a useful upper bound on the extent of risk shifting that could possibly have occurred. If there were no effect of risk taking on bankruptcy probability, then this fact would purely represent risk shifting. As there is surely an effect of risk taking on bankruptcy probability, this fact overstates moral hazard.

Table 12 shows the coefficients on ex post indicators of pension fund termination when added to specifications in the previous tables. I try indicators of both one year and three years before termination in the plan level data, and one year and three years before bankruptcy in the firm level data. The goal of this exercise is to compare the asset allocation of firms that ultimately terminate with those that do not. Each cell in the table represents one regression with controls, but only the coefficient of interest is shown in the table. The pooled regressions for plan level data with controls use the specification in Table 5, column 1, augmented with the pre-termination indicator. The firm effects regressions for plan level data with controls use the specification in Table 5, column 3, augmented with the pre-termination indicator. The pooled regressions for firm level data with controls use the specification in Table 7, columns 1 and 4 , augmented with the pre-termination indicator. The firm effects regressions for firm level data with controls use the specification in Table 8 , columns 1 and 4, augmented with the pre-termination indicator.

Table 12 reveals that in most specifications there is neither a statistically nor economically significant relationship between risk taking in pension plans and ex post indicators of pension plan termination or bankruptcy. In the top panel, which considers the plan level data from the IRS 5500 filings, the one regression in which an effect appears is that in the last observation before termination a plan has a $6.1 \%$ larger allocation to stocks and $8.9 \%$ smaller allocation to government debt and cash than a plan in the same year that does not terminate. Within the plan over time, these coefficients are $3.5 \%$ and $-4.7 \%$. It is important to note that this effect only appears with this strength in the regression with controls, i.e. when all of the other observable indicators for financial distress are controlled for. This is much more suggestive of the reverse causality story than of risk shifting. It is only relative to firms with 
the same ex ante observable indicators of financial strength that firms which ultimately terminated took additional risk.

Another consideration is whether plans that actually terminated in bankruptcy had more volatile investment returns during the period of their existence than plans that did not terminate. Figure 5 shows the within-year mean investment returns of private sector plans that eventually terminated against those that did not. Additionally it shows the investment performance of the PBGC, and of the value-weighted NYSE/AMEX/Nasdaq returns including dividend distributions. The PBGC itself appears to have at least as volatile investment returns in pension fund investing compared to the universe of private sector plans. Plans that ultimately terminated do not appear to have had more volatile annual investment returns over the sample period than those that did not terminate. Time series standard deviations of returns for 19882003 for these different samples confirm this: $12.4 \%$ for the PBGC, $8.1 \%$ for value-weighted private sector returns of non-terminating plans, and $6.9 \%$ for value-weighted private sector returns of plans that did terminate. The lower graph in Figure 5 shows the same lines but net of the market return line.

Appendix Table 2 shows a more detailed analysis of the mean and standard deviation of returns for the terminating versus the non-terminating sample of firms. The top panel shows for each year the cross-sectional mean of the within-plan mean returns for plans that terminated in the listed year versus those that did not terminate though the listed year, and the cross-sectional standard deviation of those within-plan means. The lower panel shows for each year the mean of the within-plan standard deviations for terminating versus non-terminating firms. The bottom lines of each panel summarize the results for all plans. The mean returns of plans which ultimately terminated was $1.3 \%$ lower than the average, accounting for year fixed effects. Plans that ultimately terminated had an average standard deviation of $8.0 \%$, compared to firms that did not terminate which had an average standard deviation of $9.4 \%$.

The comparison of terminating versus non-terminating plans thus reveals that the investment returns of plans that terminated were no more volatile than those of plans that did not terminate, or of the PBGC's own investments.

\section{Conclusion}


Observers have often assumed that moral hazard plays a role in pension fund asset allocation. However, this study finds that plans and firms in fact have less risky pension fund asset allocations when their financial condition is weaker. Allocations of pension fund assets to safer assets (debt and cash) are higher when the plan is less funded and when the sponsor has a lower credit rating. These findings, which are robust both in the cross-section and within firms over time, run counter to the moral hazard hypothesis and suggest that risk management incentives to avoid costly financial distress dominate on average in this context. However, there appears to be zero within-year correlation between the return on pension assets and the return on operating assets, suggesting that firms do not dynamically tailor pension investments to correlate with their own investment opportunities (as would be predicted by Froot, Scharfstein and Stein (1993)). I also find that the allocation of pension fund assets to equities is positively correlated with the share of plan participants who are current employees, indicating that firms consider the duration of pension liabilities in formulating pension fund investment strategy.

The fact that risk management in pensions is empirically witnessed even close to bankruptcy stands in contrast to the evidence of moral hazard found in analyses of the incentives faced by savings and loan institutions in the 1980s. Nonetheless, one conclusion of the savings and loan literature is that risk shifting only happened at thrifts whose financial condition was extremely poor. Kroszner and Strahan (1996), for example, show that while insolvent thrifts increased dividends to shareholders, such payouts are generally positively correlated with the financial health of the institution.

Risk shifting is only one type of conflict between creditors and shareholders. Creditors clearly use covenants in loan agreements to prevent direct expropriation and value extraction by shareholders. Some forms of direct expropriation, such as spinning off profitable divisions, may have little or no risk consequences for the firm. However, it is notable that creditors do not restrict the risk behavior of firms in their pension funds. This fact suggests that it is risk management incentives and not an explicit restriction on behavior that generates the observed results.

I conclude with three natural directions for further research. First, further research is necessary to understand what appear to be non-trivial effects of lagged investment returns on asset allocation, and 
whether this is efficient or not. Second, it seems important to examine the extent to which the tradeoff between risk shifting and risk management also governs firms' chosen exposure to other risks, such as currency and foreign exchange fluctuations. Third, given that a large part of firm-level variation in asset allocation remains unexplained, further studies could aim to identify other factors that affect variation pension fund investment strategies. 


\section{Figure Legends}

\section{Figure 1: Pension Fund Asset Allocation in IRS 5500 Data}

The graphs show mean allocation to the major asset classes by year. The top graph includes insurance contracts. The sample consists of all observations for which assets in opaque investment categories were less than $5 \%$ of total assets. The bottom graph shows the share of total non-insurance assets. The sample consists of all observations for which assets in opaque investment categories were less than $5 \%$ of total assets and for which the assets are not $100 \%$ in insurance vehicles. Error bands are plus or minus two standard errors.

\section{Figure 2: Effects of Funding Status on Asset Allocation in IRS 5500 Data}

These figures show the effects of funding status decile on the percent of pension assets invested in stocks versus government debt, cash and insurance. The top graph illustrates the coefficient results from two pooled regressions of asset allocation on funding deciles with year controls. The bottom graph shows the coefficient results from two regressions of asset allocation on funding status deciles with both year controls and plan fixed effects. Coefficients are relative to the omitted category, which is the first or lowest decile.

\section{Figure 3: Distress Termination Probabilities and Asset Allocation in IRS 5500 Data}

Distress termination probabilities are estimated using the specification in the first column of Table 10 and their quantiles are plotted against beginning of year asset allocation. The top two graphs show unadjusted results and the bottom two graphs show the asset allocations net of adjustments for year fixed effects.

\section{Figure 4: Bankruptcy Probabilities and Asset Allocation in Firm-Level Data}

Distress termination probabilities are estimated using the specification in the third column of Table 11 and their quintiles are plotted against end of year asset allocation. The top two graphs show unadjusted results and the bottom two graphs show the asset allocations net of adjustments for year fixed effects.

\section{Figure 5: Investment Returns of the PBGC and the Private Sector}

Investment returns of assets held by the PBGC are from PBGC annual reports (PBGC (1995) and PBGC (2005)). The PBGC fiscal year end is in September. Value weighted NYSE/AMEX/Nasdaq returns are calculated from CRSP data from September of year (t-1) to September of year (t). I calculate valueweighted investment returns of private sector plans from the sample of IRS 5500 filings tabulated in Table 2a. Investment returns are defined as investment income divided by beginning-of-year pension assets. 


\section{References}

Acharya, V., H. Almeida and M. Campello, 2007, "Is Cash Negative Debt? A Hedging Perspective on Corporate Financial Policies," Journal of Financial Intermediation, forthcoming.

Almeida, H., M. Campello, and M. Weisbach, 2006, "Corporate Financial and Investment Policies when Future Financing is not Frictionless," Working Paper, University of Illinois.

Andrade G. and S. Kaplan, 1998, "How Costly is Financial (Not Economic) Distress? Evidence from Highly Leveraged Transactions That Became Distressed," Journal of Finance 53(5), 1443-1493.

Bergstresser, D., M. A. Desai, and J. D. Rauh, 2006, "Earnings Manipulation, Pension Assumptions, and Managerial Investment Decisions," Quarterly Journal of Economics 121(1), 157-195.

Black, F., 1980, “The Tax Consequences of Long-Run Pension Policy," Financial Analysts Journal 36, July-August, 21-29.

Bodie, Z., J. O. Light, R. Mørck, and R. A. Taggart, 1985, “Corporate Pension Policy: An Empirical Investigation,” Financial Analysts Journal 41, 10-16.

Bodie, Z., J. O. Light, R. Mørck, and R. A. Taggart, 1987, "Funding and Asset Allocation in Corporate Pension Plans: An Empirical Investigation," in Issues in Pension Economics, Zvi Bodie, John Shoven, and David Wise, eds., Chicago, University of Chicago Press, 15-47

Bodie, Z., 1995, “On the Risk of Stocks in the Long Run,” Financial Analysts Journal 51(3), 18-22.

Bodie, Z., 1990, The ABO, the PBO, and Pension Investment Policy, Financial Analysts Journal 46, $27-$ 34.

Boyce, S., and R. A. Ippolito, 2002, “The Cost of Pension Insurance,” Journal of Risk and Insurance 69, 121-170.

Buessing, M., and M. Soto, 2006, “The State of Private Pensions: Current 5500 Data,” Center for Retirement Research Issue in Brief 42.

Bulow, J., and M. Scholes, "Who Owns the Assets in a Defined-Benefit Pension Plan?" in Financial Aspects of the U.S. Pension System, Zvi Bodie and John Shoven, eds., Chicago: University of Chicago Press, 1983.

Campbell, J., and L. Viceira, 2005, "Strategic Asset Allocation for Pension Plans," prepared for the Oxford Handbook of Pensions and Retirement Income, forthcoming.

Center on Federal Financial Institutions, 2004, PBGC: A Primer.

Cocco, J., and P. Volpin, 2007, "The Corporate Governance of Defined Benefit Pension Plans: Evidence from the United Kingdom,” Financial Analysts Journal 63(1), 70-83.

Coronado, J., and N. Liang, 2005, "The Influence of PBGC Insurance on Pension Fund Finances," Pension Research Council Working Paper, 2005-10. 
Denmark, F., 2006, “Internaional Paper Company: Out of the Woods, ” Institutional Investor's Alpha, June issue, 19-29.

Friedman, B. M., 1983, "Pension Funding, Pension Asset Allocation, and Corporate Finance: Evidence from Individual Company Data," in Financial Aspects of the U.S. Pension System, Z. Bodie and J. Shoven, eds., Chicago, University of Chicago Press, 107-147.

Frieman, Adam, Justin Pettit, Azad Badakhsh, and Kyle Barker, 2005, "Optimal Capital Structure and the Corporate Pension,” UBS Investment Banking Note, UBS AG, New York.

Froot, K. A., D. S. Scharfstein, and J. C. Stein, 1993, "Risk management: Coordinating corporate investment and financing policies," Journal of Finance 48, 1629-1658.

Gold, J., 2005, “Accounting/Actuarial Bias Enables Equity Investment by Defined Benefit Pension Plans," North American Actuarial Journal.

Harris, M., and A. Raviv, 1991, "The Theory of Capital Structure,” Journal of Finance 46, 297-335.

Harrison, M. J. and W.F. Sharpe, 1983, "Optimal Funding and Asset Allocation Rules for Defined Benefit Pension Plans," in in Financial Aspects of the U.S. Pension System, Z. Bodie and J. Shoven, eds., Chicago, University of Chicago Press.

Hsieh, S.-J., A. Chen, and K. Ferris, 1994, "The Valuation of PBGC Insurance Premiums Using an Option Pricing Model," Journal of Financial and Quantitative Analysis 29, 89-99.

Ippolito, R., 2002, “The Reversion Tax’s Perverse Result,” Regulation, Spring 2002, 46-53.

Lehn, K., and A. Poulsen, 1991, "Contractual Resolution of Bondholder-Stockholder Conflicts in Leveraged Buyouts,” Journal of Law and Economics 34, 645-673.

Leland, H. E., 1998, “Agency Costs, Risk Management, and Capital Structure,” Journal of Finance 53, 1213-1243.

Lucas, D., and S. Zeldes, 2006, "Valuing and Hedging Defined Benefit Pension Obligations — The Role of Stocks Revisited,” Working Paper, Northwestern University.

Lucent Retirees Organization, 2003, "Lucent Discloses Pension Governance Process and Fund Performance," http://www.lucentretirees.org/docs/lucent_discloses_pension_governa.htm.

Jensen, M. C., and W. H. Meckling, 1976, "Theory of the Firm: Managerial Behavior, Agency Costs and Ownership Structure,” Journal of Financial Economics 3, 305-360.

Kroszner, Randall S., 2005, Testimony before the Committee on Finance, United States Senate, http://www.chicagogsb.edu/news/2005-02-28txt kroszner.pdf.

Kroszner, R. S., and P. E. Strahan, 1996, "Regulatory Incentives and the Thrift Crisis: Dividends, Mutualto-Stock Conversions, and Financial Distress,” Journal of Finance 51, 1285-1319.

Marcus, A., 1987, "Corporate Pension Policy and the Value of PBGC Insurance," in Issues in Pension Economics, Z. Bodie, J. Shoven, and D. Wise eds., Chicago, University of Chicago Press. 
Mayers, D., and C. W. Smith, 1982, “On the Corporate Demand for Insurance,” Journal of Business 55, 281-296.

Mayers, D. and C. W. Smith, 1987, "Corporate Insurance and the Underinvestment Problem," Journal of Risk and Insurance 54, 45-54.

Merton R.C. and P.A. Samuelson, 1974, "Fallacy of the Log-Normal Approximation to Portfolio Decision-Making over Many Periods," Journal of Financial Economics 1(1), 67-94.

Morellec, E., and C. W. Smith, 2007, “Agency Conflicts and Risk Management," Review of Finance 11, $1-23$.

Myers, S., 1977, “Determinants of Corporate Borrowing,” Journal of Financial Economics 5, 147-175.

Parrino, R., and M. Weisbach, 1999, "Measuring Investment Distortions Arising from StockholderBondholder Conflicts," Journal of Financial Economics 53, 3-42.

Pension Benefit Guaranty Corporation (PBGC), 1995, Pension Benefit Guaranty Corporation Annual Report, http://www.pbgc.gov/docs/1995 annual report.pdf.

Pension Benefit Guaranty Corporation (PBGC), 2005, Pension Benefit Guaranty Corporation Performance and Accountability Report, http://www.pbgc.gov/docs/2005par.pdf.

Pennacchi, G. G. and C. M. Lewis, 1994, "The Value of Pension Benefit Guaranty Corporation Insurance," Journal of Money, Credit and Banking 26, 735-753.

Petersen, M., 1992, "Pension reversions and worker-stockholder wealth transfers," Journal of Finance 107, 1033-1056.

Petersen, M., 1994, "Cashflow Variability and Firm's Pension Choice: A Role for Operating Leverage," Journal of Financial Economics, December, 1994, Volume 36, pp. 361-383

Petersen, M., 1996, “Allocating Assets and Discounting Cash Flows: Pension Plan Finance," in Pensions, Savings, and Capital Markets, eds., Phyllis A Fernandez, John A. Turner, and Richard P. Hinz, Washington, D.C., U.S. Department of Labor.

Purnanandam, A., 2007, "Financial Distress and Corporate Risk Management: Theory and Evidence," Journal of Financial Economics, forthcoming.

Rauh, J. D., 2006, "Investment and Financing Constraints: Evidence from the Funding of Corporate Pension Plans," Journal of Finance 61, 33-71.

Sameulson, P.A., 1963, "Risk and Uncertainty: A Fallacy of Large Numbers," Scientia, $6^{\text {th }}$ series, $57^{\text {th }}$ year, 1-6.

Samuelson, P.A., 1994, “The Long-Term Case for Equities and How It Can Be Oversold," The Journal of Portfolio Management 21(1), 15-24.

Samuelson, W., and R. Zeckhauser, 1988, “Status Quo Bias in Decision Making,” Journal of Risk and Uncertainty 1, 7-59. 
Smith C. and R. Stulz, 1985, “The Determinants of Firms' Hedging Policies,” Journal of Financial and Quantitative Analysis 20, 391-405.

Sharpe, W. F., “Corporate Pension Funding Policy,” Journal of Financial Economics, 1976, 183-193.

Sundaresan, S., and F. Zapatero, 1997, "Valuation, Optimal Asset Allocation and Retirement Incentives of Pension Plans," Review of Financial Studies 10, 631-660.

Sweeting, P., 2005, "Funding and Asset Allocation Strategies - Why Firms and Trustees Behave As They Do," Working Paper, Presented to the 2005 U.K. Finance and Investment Board Conference.

Treynor, J., 1977, “The Principles of Corporate Pension Finance," Journal of Finance 32, 627-638.

Tepper, I., 1981, “Taxation and Corporate Pension Policy,” Journal of Finance 36, 1-13.

Thaler, R., 1980, “Towards a Positive Theory of Consumer Choice," Journal of Economic Behavior and Organization 1, 39-60. 


\section{Footnotes}

${ }^{1}$ There is an alternative interpretation of the result that firms with a large share of active retirees invest in safer securities. Some investors, even institutional investors, may believe that stocks are a safer investment over the long run. Indeed, according to Bodie (1995), “The conventional wisdom in the professional investment community seems to be that investors with a long time horizon should invest more heavily in stocks than investors with a short time horizon." The fallacy in the so-called long-run case for equity investing is studied in Samuelson (1963), Merton and Samuelson (1974), Samuelson (1994) and Bodie (1995).

${ }^{2}$ Firms book as income an expected return on pension plan assets, and investing in equity allows that expected return to be higher than investing in securities with lower expected returns. Indeed, industry sources such as Frieman et al (2005) argue that pension accounting under GAAP is "an opaque method of accounting that highlights the rewards of equity but obscures its risks."

${ }^{3}$ Before 1986, firms could withdraw surplus pension assets essentially without penalty (see Petersen (1992)). Under this regime, the pension fund was an optimal place for storing financial slack. Firms could make voluntary contributions to the pension fund, take an immediate tax deduction, and defer all taxes on the investment earnings of the assets in the pension fund until the assets were withdrawn. Since 1986, firms have had to pay excise taxes on pension withdrawals, and since 1990 the excise tax rate has been a substantial 50\% (see Ippolito (2002)).

${ }^{4}$ The tension between risk shifting and other motivations for risk management has been a subject of other recent theoretical work. Purnanandam (2007) builds a model in which such a tension arises due to product-market related costs of financial distress. In his model, risk-shifting incentives dominate the risk-management incentives if firms are close to financial distress. Morellec and Smith (2007) consider a generalized model of agency conflicts (both stockholder-debtholder and management-stockholder) and risk management.

${ }^{5}$ See http://www.pbgc.gov/workers-retirees/find-your-pension-plan/PlanPage/ for these plan pages.

${ }^{6}$ The Boeing Corporation is excluded from this table; while it is one of the ten largest corporate DB pension sponsors, it did not respond to the Pensions and Investments survey and its asset allocation in aggregate is inscrutable in the IRS 5500s due to the very large number of separate plans that it sponsors. Unambiguous asset allocation for General Motors pension fund was not obtainable from the 5500 attachments. Northwest Airlines did not respond to the Pensions and Investments survey.

${ }^{7}$ This of course implies that the fixed effects results are not much different from the random effects results; the fixed effects coefficients are indeed very similar, just with slightly larger standard errors.

${ }^{8}$ The top group in the graph is the $1 / 100^{\text {th }}$ of the sample most likely to terminate, the second group from the top is the $1 / 100^{\text {th }}$ of the sample second most likely to terminate, etc. 


\section{Table 1: UAL Corporation (United Airlines) Defined Benefit Pension Asset Allocation}

Data on total pension assets, assets in each of the four categories (common and preferred equities, government and corporate debt, private equity, and cash and short-term instruments), and appreciation of assets in each of the four categories are collected from the attachments to the UAL Corporation 5500 filings. End-of-year category assets do not sum exactly to total end-of-year pension assets because of small amounts $(<0.3 \%)$ of real estate and other assets. The predicted share if no rebalancing assumes given appreciation during the year for each asset class and no change in asset allocation due to contributions or benefit distributions. The second-to-last column shows the predicted share assuming no dividends and interest (or alternatively assuming that dividends and interest are reinvested in the same proportion as the other assets). The final column shows the predicted share assuming dividends come from equities and are reinvested in equities while interest comes from debt and is reinvested in debt. UAL Corporation filed for Chapter 11 bankruptcy in 2002, and its pension plans were terminated in 2005.

Total End-of-Year Pension Assets (\$ thousands)
End-of-Year

Assets in

Category $(\$$

thousands)

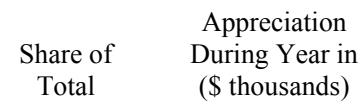

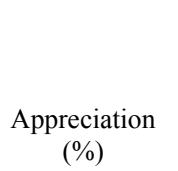

(\%)
Predicted Share if Predicted Share if No Rebalancing No Rebalancing (Assuming No (Dividends and Dividends and Interest Interest) Reinvested)

Common and Preferred Equities

\begin{tabular}{|c|c|c|c|c|c|c|c|}
\hline & & & & \\
\hline 2004 & $7,115,030$ & $4,549,841$ & $63.9 \%$ & 605,815 & $13.9 \%$ & $65.0 \%$ & $64.8 \%$ \\
\hline 2003 & $6,934,364$ & $4,361,317$ & $62.9 \%$ & $1,119,525$ & $31.5 \%$ & $61.9 \%$ & $61.7 \%$ \\
\hline 2002 & $6,248,602$ & $3,557,178$ & $56.9 \%$ & $-840,847$ & $-18.7 \%$ & $54.7 \%$ & $54.4 \%$ \\
\hline 2001 & $7,521,831$ & $4,491,800$ & $59.7 \%$ & $-629,967$ & $-12.3 \%$ & $57.1 \%$ & $56.7 \%$ \\
\hline 2000 & $8,450,291$ & $5,107,256$ & $60.4 \%$ & $-367,932$ & $-6.4 \%$ & $64.1 \%$ & $62.8 \%$ \\
\hline \multirow[t]{2}{*}{1999} & $8,631,020$ & $5,762,327$ & $66.8 \%$ & $1,131,196$ & & & \\
\hline & & \multicolumn{6}{|c|}{ Government and Corporate Debt } \\
\hline 2004 & $7,115,030$ & $1,595,315$ & $22.4 \%$ & 66,708 & $4.0 \%$ & $22.8 \%$ & $23.2 \%$ \\
\hline 2003 & $6,934,364$ & $1,678,009$ & $24.2 \%$ & 147,794 & $7.9 \%$ & $26.7 \%$ & $27.1 \%$ \\
\hline 2002 & $6,248,602$ & $1,868,887$ & $29.9 \%$ & 40,400 & $1.8 \%$ & $33.6 \%$ & $34.1 \%$ \\
\hline 2001 & $7,521,831$ & $2,198,873$ & $29.2 \%$ & 79,579 & $2.7 \%$ & $38.6 \%$ & $39.1 \%$ \\
\hline 2000 & $8,450,291$ & $2,948,235$ & $34.9 \%$ & 54,080 & $2.4 \%$ & $27.1 \%$ & $28.7 \%$ \\
\hline \multirow[t]{2}{*}{1999} & $8,631,020$ & $2,224,745$ & $25.8 \%$ & $-74,774$ & & & \\
\hline & & \multicolumn{6}{|c|}{ Private Equity } \\
\hline 2004 & $7,115,030$ & 361,315 & $5.1 \%$ & 51,516 & $14.1 \%$ & $5.5 \%$ & $5.4 \%$ \\
\hline 2003 & $6,934,364$ & 365,996 & $5.3 \%$ & 61,973 & $19.8 \%$ & $5.0 \%$ & $4.9 \%$ \\
\hline 2002 & $6,248,602$ & 313,405 & $5.0 \%$ & $-36,372$ & $-11.0 \%$ & $4.4 \%$ & $4.3 \%$ \\
\hline 2001 & $7,521,831$ & 331,107 & $4.4 \%$ & $-58,700$ & $-15.9 \%$ & $4.0 \%$ & $3.9 \%$ \\
\hline 2000 & $8,450,291$ & 370,305 & $4.4 \%$ & 99,128 & $51.3 \%$ & $3.5 \%$ & $3.4 \%$ \\
\hline \multirow[t]{2}{*}{1999} & $8,631,020$ & 193,385 & $2.2 \%$ & 10,047 & & & \\
\hline & & \multicolumn{6}{|c|}{ Cash and Short-Term Instruments } \\
\hline 2004 & $7,115,030$ & 598,529 & $8.4 \%$ & 3,478 & $0.7 \%$ & $6.8 \%$ & $6.6 \%$ \\
\hline 2003 & $6,934,364$ & 513,714 & $7.4 \%$ & $-1,420$ & $-0.3 \%$ & $6.4 \%$ & $6.3 \%$ \\
\hline 2002 & $6,248,602$ & 488,378 & $7.8 \%$ & 10,671 & $2.2 \%$ & $7.3 \%$ & $7.1 \%$ \\
\hline 2001 & $7,521,831$ & 475,535 & $6.3 \%$ & 948 & $3.9 \%$ & $0.3 \%$ & $0.3 \%$ \\
\hline 2000 & $8,450,291$ & 24,188 & $0.3 \%$ & -388 & $-0.1 \%$ & $5.3 \%$ & $5.2 \%$ \\
\hline 1999 & $8,631,020$ & 449,045 & $5.2 \%$ & $-24,989$ & & & \\
\hline
\end{tabular}


Table 2a: Plan-Level Summary Statistics, Full Sample (1988-2003)

Data are from the IRS 5500 filings. This table shows summary statistics for the full sample of defined benefit plans with plan years ending in $1988-2003$ and with greater than 100 employees. Observations are required to have information on beginning-of-year plan assets (which also had to be nonzero), contributions, investment income, and employees, and duplicated observations are removed. PBGC terminations from the termination database were merged into this data by EIN and plan number. Plan assets come from the main 5500 form (1998 and earlier) or Schedule H (1999-2003). Plan liabilities are on the OBRA87 basis for plan years ending 1990-1994 and on the RPA94 basis for plan years ending 1995-2003. Investment income is calculated as total income from the main form or Schedule $\mathrm{H}$, minus contributions minus other non-investment income. Investment returns are restricted to lie between $-80 \%$ and $+500 \%$. Contributions are from Schedule B. Asset allocation figures are only for observations with less than $5 \%$ of assets in opaque investment vehicles.

Levels (in Millions of Dollars)

Assets

Liabilities (1990-2003)

Investment Income

Contributions

M

\section{Ratios}

Last Observation before Termination

Funding Status (1990-2003)

Investment Return

Contributions / Assets

Active Share of Employees

Median

Deviation

Minimum

Maximum

Number of

$\begin{array}{lll}84.46 & 6.53 & 733.30\end{array}$

81.72

6.93

2.89

\subsection{4}

0.33

0.21

705.40

96.65

55.48

0.0027

0.1533

0.0886

0.0930

0.6373

0.0000

0.0428

0.0877

0.0475

0.6736

0.3864

0.1324

0.1560

0.2350

16.72

25.51

30.57

23.24

20.68

23.90

0.00

8.35

27.64

31.39

39.93

28.92

31.54

33.44

33.67

28.52

40.22

0.00

0.00

100.00

100.00

100.00

100.00

100.00

100.00

80,717

80,717

80,717

80,717

214,015

33,144

23,456

Total Unique 
Table 2b: Plan-Level Summary Statistics, Estimation Sample (1990-2003)

Data are from the IRS 5500 filings. The variable construction is as in Table 2a. The sample is all observations for which allocation of assets to opaque investment vehicles is less than $5 \%$ of total pension assets and for which liability information is available.

\begin{tabular}{|c|c|c|c|c|c|c|}
\hline & Mean & Median & $\begin{array}{r}\text { Standard } \\
\text { Deviation } \\
\end{array}$ & Minimum & Maximum & $\begin{array}{r}\text { Number of } \\
\text { Observations }\end{array}$ \\
\hline \multicolumn{7}{|l|}{ Levels (in Millions of Dollars) } \\
\hline Assets & 47.50 & 6.24 & 506.19 & 0.00 & 49681.07 & 55,684 \\
\hline Liabilities (1990-2003) & 42.67 & 5.31 & 423.60 & 0.00 & 44170.00 & 55,684 \\
\hline Investment Income & 3.65 & 0.32 & 53.11 & -3703.00 & 6273.00 & 55,684 \\
\hline Contributions & 1.64 & 0.23 & 18.91 & 0.00 & 3963.00 & 55,684 \\
\hline \multicolumn{7}{|l|}{ Ratios } \\
\hline Last Observation before Termination & 0.0025 & 0.0000 & 0.0497 & 0.0000 & 1.0000 & 55,684 \\
\hline Funding Status (1990-2003) & 0.1826 & 0.0800 & 0.3917 & -0.4839 & 1.6583 & 55,684 \\
\hline Investment Return & 0.0830 & 0.0788 & 0.1201 & -0.8000 & 5.0000 & 55,684 \\
\hline Contributions / Assets & 0.0853 & 0.0465 & 0.1370 & 0.0000 & 1.0506 & 55,684 \\
\hline Active Share of Employees & 0.6463 & 0.6809 & 0.2254 & 0.0000 & 1.0000 & 55,684 \\
\hline \multicolumn{7}{|l|}{ Asset Allocation (in \%) } \\
\hline Allocation to Corporate Equity & 28.59 & 28.22 & 27.40 & 0.00 & 100.00 & 55,684 \\
\hline Allocation to Government Debt and Cash & 28.99 & 24.16 & 28.61 & 0.00 & 100.00 & 55,684 \\
\hline Allocation to Insurance Company Accounts & 21.73 & 0.00 & 39.11 & 0.00 & 100.00 & 55,684 \\
\hline Allocation to All Other & 20.69 & 11.94 & 26.54 & 0.00 & 100.00 & 55,684 \\
\hline \multicolumn{7}{|l|}{ Allocation as Share of Non-Insurance Assets (\%) } \\
\hline Corporate Equity & 34.73 & 39.49 & 27.48 & 0.00 & 100.00 & 47,627 \\
\hline Government Debt and Cash & 37.55 & 31.78 & 29.80 & 0.00 & 100.00 & 47,627 \\
\hline Total Observations & 55,684 & & & & & \\
\hline Total Unique Plans & 6,844 & & & & & \\
\hline Total Unique Employers & 5,883 & & & & & \\
\hline
\end{tabular}


Table 3: Pension Fund Asset Allocation of Major U.S. Defined Benefit Pension Sponsors in 2003

This table shows pension fund asset allocation according to three primary sources for major U.S. defined benefit pension sponsors. The sample consists of the 10 largest pension sponsors by pension assets, excluding the Boeing Corporation, plus major airlines that filed for bankruptcy.

\begin{tabular}{|c|c|c|c|c|c|c|c|c|c|c|c|c|c|}
\hline & $\begin{array}{l}\text { General } \\
\text { Electric }\end{array}$ & IBM & SBC & Verizon & AT\&T & $\begin{array}{l}\text { General } \\
\text { Motors }\end{array}$ & $\begin{array}{l}\text { Lockheed } \\
\text { Martin }\end{array}$ & Ford Motor & $\begin{array}{c}\text { Delta } \\
\text { Airlines } \\
\end{array}$ & $\begin{array}{l}\text { Northwest } \\
\text { Airlines }\end{array}$ & $\begin{array}{c}\text { United } \\
\text { Airlines }\end{array}$ & $\begin{array}{c}\text { US } \\
\text { Airways }\end{array}$ & Lucent \\
\hline Pension Assets & 43879 & 41679 & 28154 & 42776 & 17555 & 86169 & 20913 & 37016 & 6818 & 4806 & 6961 & 1667 & 30148 \\
\hline U.S. Pension Liabilities & 37827 & 42104 & 27617 & 40968 & 15767 & 87285 & 21918 & 40463 & 12477 & 8554 & 13117 & 2589 & 31235 \\
\hline Operating Assets & 575244 & 104457 & 100166 & 167468 & 47988 & 448507 & 26175 & 295222 & 24720 & 13289 & 21185 & 8555 & 15765 \\
\hline Bankruptcy Filing & - & - & - & - & - & - & - & - & 2005 & 2005 & 2002 & 2002 & - \\
\hline Credit Rating & AAA & $\mathrm{A}+$ & $\mathrm{A}+$ & $\mathrm{A}+$ & $\mathrm{BBB}$ & $\mathrm{BBB}$ & $\mathrm{BBB}$ & BBB- & BB- & $\mathrm{B}^{+}$ & B & $\mathrm{B}$ & B- \\
\hline IRS 5500 and Attachments & Dec-02 & Dec-03 & Dec-03 & Dec-03 & Dec-03 & & Dec-03 & Dec-03 & Jun-03 & Dec-03 & Dec-03 & Dec-03 & Dec-03 \\
\hline Stocks & $54.7 \%$ & $57.6 \%$ & $61.5 \%$ & $52.6 \%$ & $56.8 \%$ & & $60.3 \%$ & $69.4 \%$ & $51.2 \%$ & $60.2 \%$ & $62.9 \%$ & $28.7 \%$ & $63.0 \%$ \\
\hline Own & $5.9 \%$ & $4.4 \%$ & $0.0 \%$ & $0.2 \%$ & $0.0 \%$ & & $0.0 \%$ & & $0.0 \%$ & & & & $0.0 \%$ \\
\hline Preferred & $0.7 \%$ & $0.2 \%$ & $0.0 \%$ & $0.3 \%$ & $0.1 \%$ & & $0.2 \%$ & & $3.6 \%$ & & & & $0.2 \%$ \\
\hline Common & $48.2 \%$ & $53.0 \%$ & $61.5 \%$ & $52.0 \%$ & $56.7 \%$ & & $60.1 \%$ & & $47.6 \%$ & & & & $62.8 \%$ \\
\hline Bonds & $27.8 \%$ & $17.1 \%$ & $12.9 \%$ & $11.3 \%$ & $23.4 \%$ & & $28.5 \%$ & $20.3 \%$ & $14.5 \%$ & $22.2 \%$ & $24.2 \%$ & $45.4 \%$ & $20.4 \%$ \\
\hline U.S. Government Bonds & $13.7 \%$ & $10.5 \%$ & $6.7 \%$ & $5.6 \%$ & $11.5 \%$ & & $18.0 \%$ & $11.7 \%$ & $4.9 \%$ & & & $30.4 \%$ & $13.6 \%$ \\
\hline Other Bonds & $14.2 \%$ & $6.7 \%$ & $6.2 \%$ & $12.0 \%$ & $11.8 \%$ & & $12.0 \%$ & $11.4 \%$ & $9.7 \%$ & & & $15.1 \%$ & $6.8 \%$ \\
\hline Cash and Equivalents & $2.5 \%$ & $4.8 \%$ & $6.4 \%$ & $16.8 \%$ & $0.8 \%$ & & $5.2 \%$ & $5.4 \%$ & $11.3 \%$ & $8.3 \%$ & $7.4 \%$ & $14.3 \%$ & $3.3 \%$ \\
\hline Private Equity & $9.9 \%$ & $8.0 \%$ & $5.0 \%$ & $12.2 \%$ & $10.6 \%$ & & $2.9 \%$ & & $14.9 \%$ & $8.7 \%$ & $5.3 \%$ & $6.2 \%$ & $8.6 \%$ \\
\hline Real Estate & $1.6 \%$ & $0.0 \%$ & $0.9 \%$ & $2.7 \%$ & $5.5 \%$ & & $0.1 \%$ & & $6.7 \%$ & & $0.0 \%$ & $2.4 \%$ & $4.0 \%$ \\
\hline Insurance & $0.0 \%$ & $0.0 \%$ & $0.0 \%$ & $0.0 \%$ & $0.0 \%$ & & $0.0 \%$ & $0.0 \%$ & $0.6 \%$ & & & & $0.0 \%$ \\
\hline Other / Unclassifiable & $3.5 \%$ & $12.5 \%$ & $13.3 \%$ & $4.4 \%$ & $2.8 \%$ & & $3.0 \%$ & $4.9 \%$ & $0.9 \%$ & $0.6 \%$ & $0.2 \%$ & $3.0 \%$ & $0.8 \%$ \\
\hline Pensions and Investments & Sep-03 & Sep-03 & Sep-03 & Sep-03 & Sep-03 & Sep-03 & Sep-03 & Sep-03 & Sep-03 & & Sep-03 & Sep-02 & Sep-03 \\
\hline Stocks & $60.0 \%$ & $59.6 \%$ & $65.0 \%$ & $61.6 \%$ & $57.0 \%$ & $52.0 \%$ & $63.0 \%$ & $71.3 \%$ & $45.0 \%$ & & $59.0 \%$ & $39.0 \%$ & $62.8 \%$ \\
\hline Own & $6.0 \%$ & $5.2 \%$ & $0.0 \%$ & $0.0 \%$ & $0.0 \%$ & $5.0 \%$ & $0.0 \%$ & $0.0 \%$ & $0.0 \%$ & & $0.0 \%$ & $0.0 \%$ & $0.0 \%$ \\
\hline U.S. & $37.0 \%$ & $32.7 \%$ & $50.0 \%$ & $38.8 \%$ & $41.0 \%$ & $28.0 \%$ & $46.0 \%$ & $47.2 \%$ & $30.0 \%$ & & $46.0 \%$ & $28.0 \%$ & $41.3 \%$ \\
\hline Non-U.S. & $17.0 \%$ & $21.7 \%$ & $15.0 \%$ & $22.7 \%$ & $16.0 \%$ & $19.0 \%$ & $17.0 \%$ & $24.1 \%$ & $15.0 \%$ & & $13.0 \%$ & $11.0 \%$ & $21.5 \%$ \\
\hline Bonds & $21.0 \%$ & $29.2 \%$ & $28.0 \%$ & $18.6 \%$ & $24.0 \%$ & $34.0 \%$ & $30.0 \%$ & $28.4 \%$ & $26.0 \%$ & & $36.0 \%$ & $45.0 \%$ & $23.9 \%$ \\
\hline U.S. & $21.0 \%$ & $26.9 \%$ & $28.0 \%$ & $14.5 \%$ & $24.0 \%$ & $29.0 \%$ & $28.0 \%$ & $28.4 \%$ & $24.0 \%$ & & $36.0 \%$ & $45.0 \%$ & $23.9 \%$ \\
\hline Non-U.S. & $0.0 \%$ & $2.3 \%$ & $0.0 \%$ & $4.1 \%$ & $0.0 \%$ & $5.0 \%$ & $2.0 \%$ & $0.0 \%$ & $2.0 \%$ & & $0.0 \%$ & $0.0 \%$ & $0.0 \%$ \\
\hline Cash & $2.0 \%$ & $0.0 \%$ & $1.0 \%$ & $2.8 \%$ & $0.0 \%$ & $0.0 \%$ & $3.0 \%$ & $0.0 \%$ & $3.0 \%$ & & $0.0 \%$ & $9.0 \%$ & $0.0 \%$ \\
\hline Private Equity & $7.0 \%$ & $7.8 \%$ & $5.0 \%$ & $10.2 \%$ & $9.0 \%$ & $5.0 \%$ & $3.0 \%$ & $0.1 \%$ & $12.0 \%$ & & $5.0 \%$ & $3.0 \%$ & $7.7 \%$ \\
\hline Real Estate & $7.0 \%$ & $3.4 \%$ & $1.0 \%$ & $3.8 \%$ & $9.0 \%$ & $8.0 \%$ & $0.0 \%$ & $0.2 \%$ & $9.0 \%$ & & $0.0 \%$ & $4.0 \%$ & $5.6 \%$ \\
\hline Other & $3.0 \%$ & $0.0 \%$ & $0.0 \%$ & $3.1 \%$ & $1.0 \%$ & $1.0 \%$ & $1.0 \%$ & $0.0 \%$ & $5.0 \%$ & & $0.0 \%$ & $0.0 \%$ & $0.0 \%$ \\
\hline SEC 10-K Filing & Dec-03 & Dec-03 & Dec-03 & Dec-03 & Dec-03 & Dec-03 & Dec-03 & Dec-03 & Sep-03 & Dec-03 & Dec-03 & Dec-03 & Sep-03 \\
\hline Stocks / Equities & $73 \%$ & $67.5 \%$ & $66 \%$ & $55.9 \%$ & $68 \%$ & $49 \%$ & $63 \%$ & $72.2 \%$ & $50 \%$ & $70.8 \%$ & $60 \%$ & $39.0 \%$ & $63 \%$ \\
\hline Bonds and Cash & $20 \%$ & $29.2 \%$ & $27 \%$ & $17.3 \%$ & $23 \%$ & $31 \%$ & $33 \%$ & $26.3 \%$ & $25 \%$ & $20.0 \%$ & $35 \%$ & $46.0 \%$ & $24 \%$ \\
\hline Real Estate & $1 \%$ & $3.3 \%$ & $3 \%$ & $3.3 \%$ & $9 \%$ & $8 \%$ & & $0.2 \%$ & $14 \%$ & & & $4.0 \%$ & $5 \%$ \\
\hline Other & $6 \%$ & & $4 \%$ & $23.5 \%$ & $0 \%$ & $12 \%$ & $4 \%$ & $1.3 \%$ & $11 \%$ & $9.2 \%$ & $5 \%$ & $11.0 \%$ & $8 \%$ \\
\hline
\end{tabular}




\section{Table 4: Firm-Level Summary Statistics (1997-2004)}

Pension asset allocation data are from the annual Pensions and Investments survey of the top 1,000 pension sponsors. Firm characteristics are from Compustat. Pension characteristics are from Compustat and SEC 10-K filings. Firms incorporated outside the U.S. are removed from the sample. The S\&P credit rating variable (data280) is scaled so that values are between zero and one with higher values implying better credit ratings. If the firm has a AAA credit rating then the credit rating variable equals 0.929 , if the firm has a D rating then the credit rating variable has a value of 0.036 , and each of the 28 rating steps in between raises the credit rating variable by 0.036 (or 1/28). Altman's Z-Score is $(3.3 *$ EBIT / Operating Assets $)+($ Sales / Operating Assets $)+1.4 *($ Retained Earnings / Operating Assets $)+1.2 *(\mathrm{Net}$ Working Capital / Operating Assets). Debt to cash flow is total long short-term and long-term debt (data9+data34) divided by cash flow (net income + depreciation and amortization + pension expense $=$ data $14+$ data $18+$ data43). Pension assets are measured as U.S. pension assets at the end of the year as collected from SEC 10-k filings; where this information is unavailable global pension assets from the 10-k filings or Compustat (data287+data296) are used. Pension liabilities are measured as the U.S. projected benefit obligation at the end of the year as collected from SEC 10-k filings; where this information is unavailable, the global projected benefit obligation from the 10-k filings or Compustat (data286 + data294) is used. The pension funding status is pension assets minus pension liabilities, divided by pension liabilities.

\begin{tabular}{|c|c|c|c|c|c|}
\hline & Mean & Median & $\begin{array}{r}\text { Standard } \\
\text { Deviation } \\
\end{array}$ & Minimum & Maximum \\
\hline \multicolumn{6}{|l|}{ Firm Characteristics } \\
\hline S\&P Credit Rating ( 0 to 1 ) & 0.605 & 0.643 & 0.219 & 0.000 & 0.929 \\
\hline No S\&P Credit Rating & 0.087 & 0.000 & 0.282 & 0.000 & 1.000 \\
\hline Operating Assets ( $\$$ billions) & 24.66 & 8.22 & 77.76 & 0.03 & 1264.03 \\
\hline Ln(Operating Assets in \$ millions) & 9.084 & 9.015 & 1.267 & 3.230 & 14.050 \\
\hline Altman's Z-Score & 1.558 & 1.496 & 0.861 & -2.412 & 5.025 \\
\hline Cash Flow to Assets Ratio & 0.087 & 0.086 & 0.080 & -1.318 & 0.920 \\
\hline $\begin{array}{l}\text { Standard Deviation of Operating Cash Flow } \\
\text { Over Lagged Book Assets }\end{array}$ & 0.042 & 0.038 & 0.022 & 0.006 & 0.199 \\
\hline Investment Return $\dagger$ & 0.082 & 0.114 & 0.118 & -0.283 & 0.502 \\
\hline \multicolumn{6}{|l|}{ Pension Characteristics } \\
\hline Pension assets ( $\$$ billions) & 3.521 & 1.191 & 14.440 & 0.013 & 583.963 \\
\hline Ln(Pension assets in $\$$ millions $)$ & 7.187 & 7.083 & 1.230 & 2.565 & 13.278 \\
\hline Pension Liabilities / Operating Assets & 0.202 & 0.171 & 0.131 & 0.000 & 0.442 \\
\hline Pension Funding Status & 0.052 & 0.004 & 0.303 & -0.505 & 1.168 \\
\hline \multicolumn{6}{|l|}{ Asset Allocation (\%) } \\
\hline Debt and Cash & 30.41 & 30.00 & 11.45 & 0.00 & 100.00 \\
\hline Equity (Publicly Traded) & 63.20 & 64.33 & 12.47 & 0.00 & 100.00 \\
\hline Private Equity and Real Estate & 3.54 & 1.00 & 4.76 & 0.00 & 24.00 \\
\hline All Other & 2.85 & 0.00 & 9.29 & -1.20 & 100.00 \\
\hline Total Observations & 2,186 & & & & \\
\hline Total Unique Firms & 438 & & & & \\
\hline Number of Bankruptcies & 16 & & & & \\
\hline
\end{tabular}

$\dagger$ The number of observations for this variable is only 2,008 . 


\section{Table 5: Pension Fund Asset Allocation and Plan Characteristics}

The sample consists of all observations for which assets in opaque investments were less than $5 \%$ of total assets. See Table $2 \mathrm{~b}$ for summary statistics and variable construction. In the second and fourth columns, lagged investment returns are included as a control. The sample for these columns consists of those observations for which lagged information is available. All variables are calculated from the IRS 5500 data and are measured as of the beginning of the plan year. The investment return is calculated return on pension assets in the previous year.

Funding Status
Active Share of
Employees

Assets ( $\$$ billions)

Ln(Assets)

Investment Return (t-1)

R-squared

Funding Status

Active Share of

Employees

Assets ( $\$$ billions)

Ln(Assets)

Investment Return (t-1)

R-squared

Year Fixed Effects

Plan Fixed Effects

Observations

All standard errors are heteroskedasticity robust and clustered by
Percent of Pension Invested in Equity

\begin{tabular}{cccc}
\multicolumn{4}{c}{ Percent of Pension Invested in Equity } \\
\hline $6.76^{* * *}$ & $5.45^{* * *}$ & $2.29^{* * *}$ & $1.63^{* * *}$ \\
$(0.57)$ & $(0.65)$ & $(0.43)$ & $(0.50)$ \\
$3.76^{* * *}$ & $4.32^{* * *}$ & $3.44^{* * *}$ & $3.05^{* *}$ \\
$(1.06)$ & $(1.14)$ & $(1.19)$ & $(1.34)$ \\
$-1.53^{* *}$ & $-1.54^{* *}$ & $-0.86^{* *}$ & -0.52 \\
$(0.71)$ & $(0.72)$ & $(0.39)$ & $(0.69)$ \\
$4.80^{* * *}$ & $4.57^{* * *}$ & $3.20^{* * *}$ & $2.23^{* * *}$ \\
$(0.13)$ & $(0.15)$ & $(0.50)$ & $(0.62)$ \\
& $29.21^{* * *}$ & & $9.88^{* * *}$ \\
0.19 & $(5.26)$ & & $(1.92)$ \\
& 0.19 & 0.22 & 0.22
\end{tabular}

Percent of Pension Invested in Government Debt, Cash, and Insurance

statistically significant at the $5 \%$ level, * statistically significant at the $10 \%$ level. 


\section{Table 6: Pension Fund Asset Allocation Excluding Insurance and Plan Characteristics}

The sample consists of all observations in Table $2 \mathrm{~b}$ for which pension assets are not $100 \%$ held in insurance company general accounts. In the second and fourth columns, lagged investment returns are included as a control. The sample for these columns consists of those observations for which lagged information is available. All variables are calculated from the IRS 5500 data and are measured as of the beginning of the plan year. The investment return is calculated return on pension assets in the previous year.

\begin{tabular}{|c|c|c|c|c|}
\hline \multirow{3}{*}{ Funding Status } & \multicolumn{4}{|c|}{ Percent of Non-Insurance Pension Assets Invested in Equity } \\
\hline & $9.29 * * *$ & $8.10 * * *$ & $2.86 * * *$ & $2.35 * * *$ \\
\hline & $(0.61)$ & $(0.71)$ & $(0.51)$ & $(0.59)$ \\
\hline \multirow{2}{*}{$\begin{array}{l}\text { Active Share of } \\
\text { Employees }\end{array}$} & $5.43 * * *$ & $6.33 * * *$ & $3.44 * *$ & 2.32 \\
\hline & (1.14) & $(1.23)$ & $(1.42)$ & $(1.62)$ \\
\hline \multirow[t]{2}{*}{ Assets ( $\$$ billions) } & $-1.33 * *$ & $-1.26 * *$ & $-1.06^{* *}$ & -0.70 \\
\hline & $(0.64)$ & $(0.62)$ & $(0.51)$ & $(0.79)$ \\
\hline \multirow[t]{2}{*}{ Ln(Assets) } & $3.65 * * *$ & $3.34 * * *$ & $3.00 * * *$ & $1.80^{* * *}$ \\
\hline & $(0.14)$ & $(0.16)$ & $(0.58)$ & $(0.69)$ \\
\hline \multirow[t]{2}{*}{ Investment Return ( $\mathrm{t}-1)$} & & $27.59 * * *$ & & $10.34 * * *$ \\
\hline & & $(5.74)$ & & $(2.27)$ \\
\hline \multirow[t]{2}{*}{ R-squared } & 0.16 & 0.16 & 0.05 & 0.05 \\
\hline & Percent of Non-I & Pension Asse & Invested in Gov & Debt and Cash \\
\hline \multirow[t]{2}{*}{ Funding Status } & $-7.39 * * *$ & $-6.75 * * *$ & $-1.83 * * *$ & $-2.00 * * *$ \\
\hline & $(0.65)$ & $(0.75)$ & $(0.64)$ & $(0.71)$ \\
\hline \multirow{2}{*}{$\begin{array}{l}\text { Active Share of } \\
\text { Employees }\end{array}$} & $-5.70 * *$ & $-6.62 * *$ & -2.86 & $-3.77 * *$ \\
\hline & $(1.28)$ & $(1.39)$ & (1.79) & (1.91) \\
\hline \multirow[t]{2}{*}{ Assets ( $\$$ billions) } & $0.38 * * *$ & $0.26 * *$ & $0.98 *$ & 0.84 \\
\hline & $(0.16)$ & $(0.15)$ & $(0.59)$ & $(0.61)$ \\
\hline \multirow[t]{2}{*}{ Ln(Assets) } & $-2.41 * * *$ & $-2.18 * * *$ & $-5.09 * * *$ & $-3.93 * * *$ \\
\hline & $(0.15)$ & $(0.17)$ & $(0.75)$ & $(0.89)$ \\
\hline \multirow[t]{2}{*}{ Investment Return ( $\mathrm{t}-1)$} & & $-6.10^{*}$ & & -2.80 \\
\hline & & $(3.31)$ & & $(1.75)$ \\
\hline R-squared & 0.05 & 0.05 & 0.02 & 0.02 \\
\hline Year Fixed Effects & Y & Y & Y & Y \\
\hline Plan Fixed Effects & $\mathrm{N}$ & $\mathrm{N}$ & $\mathrm{Y}$ & $\mathrm{Y}$ \\
\hline Observations & 47,627 & 38,810 & 47,627 & 38,810 \\
\hline
\end{tabular}

All standard errors are heteroskedasticity robust and clustered by firm. *** statistically significant at the $1 \%$ level, ** statistically significant at the $5 \%$ level, ${ }^{*}$ statistically significant at the $10 \%$ level. 
Table 7: Pension Fund Asset Allocation and Firm Characteristics, Pooled Specifications

This table presents regression results using firm-level data from Compustat and Pensions and Investments. See Table 4 for summary statistics. Dependent variables are measured as of September $30^{\text {th }}$. Explanatory variables and controls are measured as of the end of the fiscal year. Year effects are accounted for in all specifications by demeaning the data by year before estimation. Firm effects are not included in this table.

S\&P Credit Rating

No S\&P Credit Rating

Ln(Operating Assets)

Ln(Pension Assets)

Z-Score

Standard Deviation of Operating Cash Flow

Pension Funding Status

Pension Obligation / Operating Assets

Cash Flow to Assets Ratio

Observations

Firms

R-squared

\begin{tabular}{c} 
Percentage \\
$(1)$ \\
\hline$-6.11^{*}$ \\
$(3.43)$ \\
-2.01 \\
$(2.92)$ \\
0.31 \\
$(0.60)$ \\
-0.33 \\
$(0.48)$
\end{tabular}

$(3.43)$

2.92)

0.31

-0.33
$0.48)$

(0.4)
0.01 f Assets Invested in Debt \& Cash

\begin{tabular}{rr}
$(2)$ & $(3)$ \\
$-6.93 *$ & -5.26 \\
$(3.68)$ & $(4.28)$ \\
-2.45 & -1.22 \\
$(2.96)$ & $(3.16)$ \\
0.19 & -0.47 \\
$(0.56)$ & $(0.74)$ \\
-0.29 & 0.37 \\
$(0.48)$ & $(0.71)$ \\
-0.13 & -0.12 \\
$(0.51)$ & $(0.51)$ \\
-0.29 & -0.28 \\
$(0.18)$ & $(0.17)$ \\
& -2.60 \\
& $(2.47)$ \\
& -5.30 \\
& $(5.73)$ \\
& -3.81 \\
2,186 & $(4.40)$ \\
\hline
\end{tabular}

Percentage of Assets Invested in Equity

\begin{tabular}{ccc}
$(4)$ & $(5)$ & $(6)$ \\
\hline $10.54 * * *$ & $9.94 *$ & $8.03 *$ \\
$(3.91)$ & $(4.04)$ & $(4.62)$ \\
$6.50 * *$ & $6.09 *$ & 4.72 \\
$(3.12)$ & $(3.15)$ & $(3.36)$ \\
$-1.60 * *$ & $-1.49 * *$ & -1.26 \\
$(0.70)$ & $(0.67)$ & $(1.06)$ \\
0.54 & 0.53 & 0.34 \\
$(0.60)$ & $(0.60)$ & $(1.04)$ \\
& 0.33 & 0.33 \\
& $(0.55)$ & $(0.56)$ \\
& 0.05 & 0.08 \\
& $(0.22)$ & $(0.23)$ \\
& & 2.45 \\
& & $(2.46)$ \\
& & 0.57 \\
& & $(7.21)$ \\
2,186 & & 3.48 \\
448 & & $(4.64)$ \\
0.02 & 2,186 & 2,186 \\
& 448 & 448 \\
& 0.02 & 0.02 \\
\hline significant at the $5 \%$ level, * statistically significant
\end{tabular}

$\begin{array}{ll}448 & 448 \\ 0.01 & 0.01\end{array}$

$0.01 \quad 0.02$

* statistically significant at the $1 \%$ level, **

at the $10 \%$ level. 
Table 8: Pension Fund Asset Allocation and Firm Characteristics, Random Effects Specifications

This table presents regression results using firm-level data from Compustat and Pensions and Investments. See Table 2 for summary statistics. Dependent variables are measured as of September $30^{\text {th }}$. Explanatory variables and controls are measured as of the end of the fiscal year. Year effects are accounted for in all specifications by demeaning the data by year before estimation. The random effects estimator is used to account for firm-level unobservables. The Hausman $\chi^{2}$ Statistic is the test statistic for the Hausman test of the random firm effects model versus an otherwise identical firm fixed effects model. The probability associated with the $\chi^{2}$ statistic is the probability with which the consistency of random effects can be safely not rejected (so that probabilities close to one are supportive of the consistency of random effects).

\begin{tabular}{|c|c|c|c|c|c|c|}
\hline & \multicolumn{3}{|c|}{ Percentage of Assets Invested in Debt \& Cash } & \multicolumn{3}{|c|}{ Percentage of Assets Invested in Equity } \\
\hline & $(1)$ & $(2)$ & $(3)$ & $(4)$ & $(5)$ & $(6)$ \\
\hline \multirow[t]{2}{*}{ S\&P Credit Rating } & $-6.06 * *$ & $-6.40 * *$ & $-6.06 * *$ & $9.75 * * *$ & $9.30 * * *$ & $8.92 * *$ \\
\hline & $(3.00)$ & $(3.02)$ & $(3.07)$ & $(3.63)$ & $(3.55)$ & $(3.54)$ \\
\hline \multirow[t]{2}{*}{ No S\&P Credit Rating } & -2.57 & -2.77 & -2.56 & $5.11 * *$ & $4.85 * *$ & $4.54 *$ \\
\hline & $(2.12)$ & $(2.09)$ & $(2.07)$ & $(2.50)$ & $(2.43)$ & $(2.39)$ \\
\hline \multirow[t]{2}{*}{ Ln(Operating Assets) } & -0.30 & -0.25 & -0.17 & $-1.23 * *$ & $-1.16 * *$ & -0.78 \\
\hline & $(0.46)$ & $(0.45)$ & $(0.50)$ & $(0.54)$ & $(0.52)$ & $(0.61)$ \\
\hline \multirow[t]{2}{*}{ Ln(Pension Assets) } & -0.03 & -0.04 & -0.07 & 0.80 & 0.79 & 0.46 \\
\hline & $(0.33)$ & $(0.33)$ & $(0.34)$ & $(0.49)$ & $(0.49)$ & $(0.56)$ \\
\hline \multirow[t]{2}{*}{ Z-Score } & & 0.19 & 0.16 & & 0.25 & 0.34 \\
\hline & & $(0.40)$ & $(0.41)$ & & $(0.47)$ & $(0.47)$ \\
\hline \multirow[t]{2}{*}{ Pension Funding Status } & & & -1.19 & & & 2.05 \\
\hline & & & $(1.42)$ & & & $(1.51)$ \\
\hline \multirow[t]{2}{*}{ Pension Obligation / Operating Assets } & & & 1.80 & & & 3.40 \\
\hline & & & $(3.86)$ & & & $(4.34)$ \\
\hline \multirow[t]{2}{*}{ Cash Flow to Assets Ratio } & & & 0.13 & & & -1.16 \\
\hline & & & $(2.41)$ & & & $(1.94)$ \\
\hline Hausman $\chi^{2}$ (Fixed vs. Random Effects) & 0.88 & 1.93 & 3.82 & 1.40 & 1.59 & 3.29 \\
\hline Probability $>\chi^{2}$ & 0.9277 & 0.8584 & 0.8731 & 0.8433 & 0.9021 & 0.9145 \\
\hline Reject Consistency of Random Effects? & $\mathrm{N}$ & $\mathrm{N}$ & $\mathrm{N}$ & $\mathrm{N}$ & $\mathrm{N}$ & $\mathrm{N}$ \\
\hline Observations & 2,186 & 2,186 & 2,186 & 2,186 & 2,186 & 2,186 \\
\hline Firms & 448 & 448 & 448 & 448 & 448 & 448 \\
\hline R-squared & 0.01 & 0.01 & 0.01 & 0.02 & 0.02 & 0.02 \\
\hline
\end{tabular}


Table 9: Effects of Lagged Investment Returns on Pension Fund Asset Allocation

The investment return is the return on pension assets measured as pension fund investment appreciation (or depreciation) in dollars during the fiscal year divided by the beginningof-year pension assets. Dependent variables are measured as of September $30^{\text {th }}$, and other explanatory variables and controls are measured as of the end of the fiscal year. This table presents regression results using firm-level data from Compustat and Pensions and Investments. See Table 2 for summary statistics. Year effects are accounted for in al specifications by demeaning the data by year before estimation. The Hausman $\chi^{2}$ Statistic is the test statistic for the Hausman test of the random firm effects model versus the firm fixed effects model in the same panel. The probability associated with the $\chi^{2}$ statistic is the probability with which the consistency of random effects can be safely not rejected (so that probabilities close to one are supportive of the consistency of random effects).

\begin{tabular}{|c|c|c|c|c|c|c|}
\hline & \multicolumn{3}{|c|}{ Percentage of Assets Invested in Debt \& Cash } & \multicolumn{3}{|c|}{ Percentage of Assets Invested in Equity } \\
\hline & $(1)$ & $(2)$ & $(3)$ & $(4)$ & $(5)$ & $(6)$ \\
\hline \multirow[t]{2}{*}{ Investment Return } & $-7.72 *$ & -1.51 & -3.22 & $9.98 * *$ & 5.08 & $7.12 * *$ \\
\hline & $(4.14)$ & $(2.53)$ & $(2.40)$ & $(4.50)$ & $(3.10)$ & $(2.86)$ \\
\hline \multirow[t]{2}{*}{ S\&P Credit Rating } & $-6.94 *$ & $-8.33 * *$ & $-7.17 * *$ & $10.14 * *$ & $9.55 * *$ & $9.80 * * *$ \\
\hline & $(3.88)$ & $(4.19)$ & $(2.96)$ & $(4.15)$ & $(4.36)$ & $(3.31)$ \\
\hline \multirow[t]{2}{*}{ No S\&P Credit Rating } & -2.50 & $-4.69 *$ & $-3.66 *$ & $6.19 *$ & $4.83 *$ & $5.13 * *$ \\
\hline & $(3.09)$ & $(2.77)$ & $(2.03)$ & $(3.24)$ & $(2.80)$ & $(2.26)$ \\
\hline \multirow[t]{2}{*}{ Ln(Operating Assets) } & 0.44 & -0.90 & -0.21 & $-1.82 * * *$ & -0.84 & $-1.43 * *$ \\
\hline & $(0.60)$ & $(1.00)$ & $(0.54)$ & $(0.68)$ & $(1.15)$ & $(0.61)$ \\
\hline \multirow[t]{2}{*}{ Ln(Pension Assets) } & -0.55 & -0.63 & -0.30 & 0.84 & $3.76^{*}$ & $1.25 *$ \\
\hline & $(0.55)$ & $(1.22)$ & $(0.55)$ & $(0.66)$ & $(1.95)$ & $(0.75)$ \\
\hline \multirow[t]{2}{*}{ Z-Score } & -0.29 & 0.50 & 0.03 & 0.62 & 0.37 & 0.69 \\
\hline & $(0.54)$ & $(0.75)$ & $(0.42)$ & $(0.58)$ & $(0.89)$ & $(0.51)$ \\
\hline Estimation & OLS & $\mathrm{FE}$ & $\mathrm{RE}$ & OLS & FE & $\mathrm{RE}$ \\
\hline Hausman $\chi^{2}$ (Fixed vs. Random Effects) & - & - & 9.36 & - & - & 4.58 \\
\hline Probability $>\chi^{2}$ & - & - & 0.1545 & - & - & 0.5985 \\
\hline Reject Consistency of Random Effects? & - & - & $\mathrm{N}$ & - & - & $\mathrm{N}$ \\
\hline Observations & 2008 & 2008 & 2008 & 2008 & 2008 & 2008 \\
\hline Firms & 407 & 407 & 407 & 407 & 407 & 407 \\
\hline R-squared & 0.01 & 0.01 & 0.01 & 0.02 & 0.02 & 0.02 \\
\hline
\end{tabular}




\section{Table 10: Predictions of Distress Terminations at the Plan Level}

Each column represents a logit regression of distress termination on plan-specific characteristics from the IRS 5500 data. Standard errors clustered by firm are in parentheses, and odds ratios are in brackets below them. The dependent variable is measured as the year before a PBGC termination filing. Both regressions contain year fixed effects.

Funding Status

Active Share of Employees

Assets

$\operatorname{Ln}($ Assets $)$

Investment Return

Funding Status Decile 2

Funding Status Decile 3

Funding Status Decile 4

Funding Status Decile 5

Funding Status Decile 6

Funding Status Decile 7

Funding Status Decile 8

Funding Status Decile 9

Funding Status Decile 10 [Best]

Observations
$-2.159 *$
$(0.255)$
$[0.115]$

$-2.343 * * *$

$(0.168)$

[0.096]

0.037

(0.033)

[1.037]

$-0.202 * * *$

(0.030)

[0.817]

$-1.977 * * *$

$(0.399)$

[0.139]

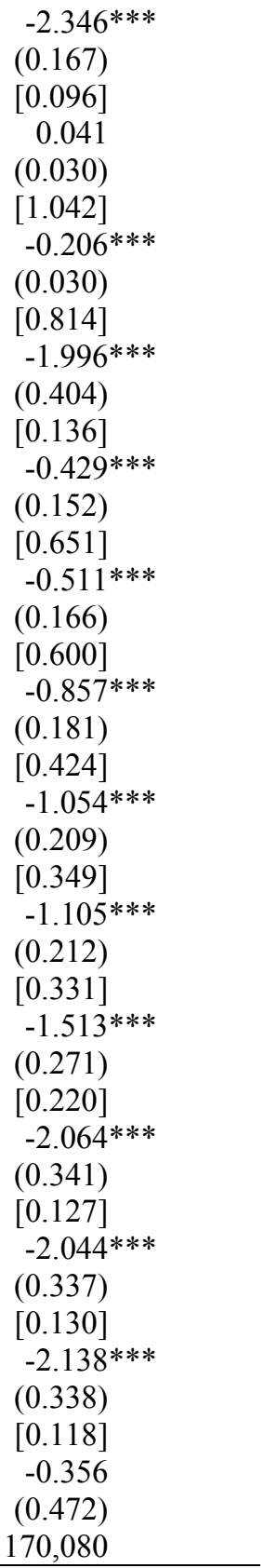

Standard errors are heteroskedasticity robust and clustered by firm. *** statistically significant at the $1 \%$ level, ** statistically significant at the $5 \%$ level, * statistically significant at the $10 \%$ level. 
Table 11: Logit Predictions of Bankruptcy for DB Sponsors at the Firm Level

Each column represents a logit regression of bankruptcy on plan-specific characteristics from the IRS 5500 data. Standard errors clustered by firm are in parentheses, and odds ratios are in brackets below them. The dependent variable is measured as the year before a CRSP delisting, or the last year of data before the bankruptcy filing if the stock was not delisted or was delisted before the bankruptcy filing

\begin{tabular}{|c|c|c|c|c|}
\hline \multirow{3}{*}{ S\&P Credit Rating } & \multicolumn{4}{|c|}{ Dependent Variable: Year Before Bankruptcy [0/1] } \\
\hline & $-8.964 * * *$ & $-5.358 * * *$ & $-4.825 * * *$ & $-4.315 * * *$ \\
\hline & $(1.247)$ & $(1.500)$ & $(1.536)$ & $(1.535)$ \\
\hline & [0.0001] & [0.0047] & {$[0.0080]$} & {$[0.0134]$} \\
\hline \multirow[t]{3}{*}{ No S\&P Credit Rating } & $-3.674 * * *$ & $-1.587 * *$ & $-1.284 *$ & -1.048 \\
\hline & $(0.800)$ & $(0.755)$ & $(0.768)$ & $(0.703)$ \\
\hline & {$[0.0254]$} & {$[0.2045]$} & {$[0.2770]$} & {$[0.3505]$} \\
\hline \multirow[t]{3}{*}{ Ln(Operating Assets) } & -0.297 & -0.284 & -0.210 & -0.091 \\
\hline & $(0.254)$ & $(0.254)$ & $(0.243)$ & $(0.382)$ \\
\hline & {$[0.7433]$} & {$[0.7528]$} & {$[0.8105]$} & {$[0.9128]$} \\
\hline \multirow[t]{3}{*}{ Ln(Pension Assets) } & $0.405 * *$ & $0.325^{*}$ & $0.312 *$ & 0.174 \\
\hline & $(0.172)$ & $(0.183)$ & $(0.176)$ & $(0.338)$ \\
\hline & [1.4986] & {$[1.3843]$} & {$[1.3656]$} & {$[1.1900]$} \\
\hline \multirow[t]{3}{*}{ Z-Score } & & -0.256 & -0.249 & -0.172 \\
\hline & & $(0.294)$ & $(0.284)$ & $(0.290)$ \\
\hline & & {$[0.7741]$} & {$[0.7800]$} & {$[0.8420]$} \\
\hline \multirow[t]{3}{*}{ Standard Deviation of Operating Cash Flow } & & & $0.184 * * *$ & $0.169 * *$ \\
\hline & & & $(0.069)$ & $(0.082)$ \\
\hline & & & [1.2025] & [1.1842] \\
\hline \multirow{3}{*}{ Pension Obligation/ Operating Assets } & & & & 2.488 \\
\hline & & & & $(2.444)$ \\
\hline & & & & {$[12.0345]$} \\
\hline \multirow[t]{3}{*}{ Pension Funding Status } & & & & -0.922 \\
\hline & & & & $(1.338)$ \\
\hline & & & & [0.3979] \\
\hline \multirow{3}{*}{ Cash Flow to Assets Ratio } & & $-0.179 * * *$ & $-0.180 * * *$ & $-0.167 * * *$ \\
\hline & & $(0.038)$ & $(0.039)$ & $(0.045)$ \\
\hline & & {$[0.8365]$} & [0.8349] & {$[0.8466]$} \\
\hline \multirow[t]{2}{*}{ Constant } & -0.4559 & -0.9594 & -2.7956 & $-3.8629 *$ \\
\hline & $(2.010)$ & (1.959) & (1.985) & (2.203) \\
\hline Observations & 2,186 & 2,186 & 2,186 & 2,186 \\
\hline
\end{tabular}

Robust standard errors in parentheses

Standard errors are heteroskedasticity robust and clustered by firm. *** statistically significant at the $1 \%$ level, ** statistically significant at the $5 \%$ level, * statistically significant at the $10 \%$ level. 


\section{Table 12: Pension Fund Asset Allocation Before Distress Terminations}

This table shows the coefficients on ex-post indicators of pension fund termination if added to regressions in the previous tables, in order to compare the asset allocation of firms that ultimately terminate with firms that do not. This effect represents an upper bound on risk-shifting because it also reflects the fact that firms more heavily invested in risky securities for reasons unrelated to the insurance incentive are also more likely to file for bankruptcy. Each cell represents one regression with controls, although only the coefficient of interest in shown here. The pooled regressions for plan level data with controls use the specification in Table 5, column 1, augmented with the pre-termination indicator. The firm effects regressions for plan level data with controls use the specification in Table 5, column 3, augmented with the pre-termination indicator. The pooled regressions for firm level data with controls use the specification in Table 7, columns 1 and 4, augmented with the pre-termination indicator. The firm effects regressions for firm level data with controls use the specification in Table 8, columns 1 and 4, augmented with the pre-termination indicator.

Specification

Dependent Variable

\begin{tabular}{cc}
\hline Pooled \\
\hline \\
Government \\
Debt, Cash, \\
Stocks & Insurance
\end{tabular}

Plan/Firm Fixed Effects

$\begin{array}{cc}\text { Government } \\ \text { Debt, Cash, } \\ \text { Stocks } & \text { Insurance }\end{array}$

$\underline{\text { Plan Level Data from IRS 5500s }(\mathrm{N}=55,684)}$

\begin{tabular}{|c|c|c|c|c|}
\hline $\begin{array}{l}\text { Indicator if Last Observation Before Termination } \\
\text { Regression without Controls }\end{array}$ & $\begin{array}{r}-1.391 \\
(1.897)\end{array}$ & $\begin{array}{r}3.523 \\
(2.605)\end{array}$ & $\begin{array}{r}2.551 \\
(1.618)\end{array}$ & $\begin{array}{l}-1.712 \\
(2.437)\end{array}$ \\
\hline $\begin{array}{l}\text { Indicator if Three Years Before Termination } \\
\text { Regression without Controls }\end{array}$ & $\begin{array}{l}-2.052 \\
(2.777)\end{array}$ & $\begin{array}{r}0.490 \\
(3.835)\end{array}$ & $\begin{array}{r}-2.213 \\
(1.793)\end{array}$ & $\begin{array}{r}0.923 \\
(2.339)\end{array}$ \\
\hline $\begin{array}{l}\text { Indicator if Last Observation Before Termination } \\
\text { Regression with Controls }\end{array}$ & $\begin{array}{l}6.128 * * * \\
(2.321)\end{array}$ & $\begin{array}{l}-8.889 * * * \\
(3.087)\end{array}$ & $\begin{array}{l}3.543 * \\
(1.860)\end{array}$ & $\begin{array}{l}-4.681 * \\
(2.807)\end{array}$ \\
\hline $\begin{array}{l}\text { Indicator if Three Years Before Termination } \\
\text { Regression with Controls }\end{array}$ & $\begin{array}{r}1.981 \\
(3.247)\end{array}$ & $\begin{array}{r}-3.660 \\
(4.408)\end{array}$ & $\begin{array}{l}-4.111 \\
(2.537)\end{array}$ & $\begin{array}{r}1.357 \\
(2.883)\end{array}$ \\
\hline
\end{tabular}

Firm Level Data from Compustat and Pensions \& Investments ( $\mathrm{N}=448)$

\begin{tabular}{|c|c|c|c|c|}
\hline $\begin{array}{l}\text { Indicator if Last Observation Before Bankruptcy } \\
\text { Regression without Controls }\end{array}$ & $\begin{array}{r}-1.967 \\
(3.418)\end{array}$ & $\begin{array}{r}-0.828 \\
(2.343)\end{array}$ & $\begin{array}{l}-3.067 \\
(2.906)\end{array}$ & $\begin{array}{r}1.715 \\
(2.406)\end{array}$ \\
\hline $\begin{array}{l}\text { Indicator if Three Years Before Bankruptcy } \\
\text { Regression without Controls }\end{array}$ & $\begin{array}{r}1.680 \\
(2.015)\end{array}$ & $\begin{array}{l}-2.269 * \\
(1.376)\end{array}$ & $\begin{array}{r}2.739 \\
(2.089)\end{array}$ & $\begin{array}{r}-0.634 \\
(1.036)\end{array}$ \\
\hline $\begin{array}{l}\text { Indicator if Last Observation Before Bankruptcy } \\
\text { Regression with Controls }\end{array}$ & $\begin{array}{r}-0.670 \\
(3.365)\end{array}$ & $\begin{array}{l}-2.377 \\
(2.398)\end{array}$ & $\begin{array}{r}-2.204 \\
(2.627)\end{array}$ & $\begin{array}{r}0.988 \\
(2.154)\end{array}$ \\
\hline $\begin{array}{l}\text { Indicator if Three Years Before Bankruptcy } \\
\text { Regression with Controls }\end{array}$ & $\begin{array}{r}2.349 \\
(1.992)\end{array}$ & $\begin{array}{l}-3.105^{* *} \\
(1.473)\end{array}$ & $\begin{array}{r}2.317 \\
(2.000)\end{array}$ & $\begin{array}{r}-0.194 \\
(1.018)\end{array}$ \\
\hline
\end{tabular}

Standard errors are heteroskedasticity robust and clustered by firm. *** statistically significant at the $1 \%$ level, ** statistically significant at the $5 \%$ level, $*$ statistically significant at the $10 \%$ level. 


\section{Appendix Table 1: Bankruptcies in Firm Level Data}

This table details the 16 bankruptcies that occur in the firm level data. The overall sample is described in Table 4. There are two conventions to indicate the last year before bankruptcy. The first is the last year of data before CRSP delisting, or the last year of data before the bankruptcy filing if the delisting date of the stock cannot be identified. The second is the last year of data before bankruptcy is filed. Results in this paper are presented using the first definition although they are robust to the use of the second.

UAL (United Airlines) Corp
Delta Air Lines Inc
Northwest Airlines Corp
Bethlehem Steel Corp
Pacific Gas and Electric (PG\&E)
US Airways Group
National Steel Corp
Solutia Inc
Polaroid Corp
Owens Corning
Kaiser Aluminum \& Chemical
Weirton Steel Corp
Enron Corp
USG Corp
Consolidated Freightways
Agway Inc

\begin{tabular}{|c|c|c|c|c|c|}
\hline $\begin{array}{l}\text { Bankruptcy } \\
\text { Filing }\end{array}$ & Delisting & Termination & $\begin{array}{l}\text { Last Data } \\
\text { Year } \\
\text { Before } \\
\text { Delisting }\end{array}$ & $\begin{array}{l}\text { Last Data } \\
\text { Year } \\
\text { Before } \\
\text { Filing }\end{array}$ & $\begin{array}{l}\text { Pension } \\
\text { Liabilities }\end{array}$ \\
\hline $12 / 9 / 2002$ & $4 / 2 / 2003$ & 2005 & 2003 & 2001 & $\$ 13,117$ \\
\hline $9 / 14 / 2005$ & $10 / 12 / 2005$ & Seeking & 2004 & 2004 & $\$ 12,140$ \\
\hline $9 / 14 / 2005$ & $9 / 23 / 2005$ & Seeking & 2004 & 2004 & $\$ 9,425$ \\
\hline $10 / 15 / 2001$ & $6 / 11 / 2002$ & 2003 & 2001 & 2000 & $\$ 6,495$ \\
\hline $4 / 6 / 2001$ & - & - & 2000 & 2000 & $\$ 5,405$ \\
\hline $8 / 11 / 2002$ & $9 / 21 / 2004$ & 2003 & 2002 & 2001 & $\$ 5,287$ \\
\hline $3 / 6 / 2002$ & $3 / 15 / 2002$ & 2003 & 2001 & 2001 & $\$ 2,290$ \\
\hline $12 / 17 / 2003$ & $12 / 16 / 2003$ & - & 2001 & 2001 & $\$ 1,706$ \\
\hline $10 / 12 / 2001$ & $10 / 9 / 2001$ & 2002 & 2000 & 2000 & $\$ 1,197$ \\
\hline $10 / 5 / 2000$ & $12 / 18 / 2002$ & - & 2001 & 1999 & $\$ 1,157$ \\
\hline $2 / 12 / 2002$ & $4 / 2 / 2002$ & 2003 & 2002 & 2001 & $\$ 913$ \\
\hline $5 / 19 / 2003$ & $9 / 5 / 2001$ & 2003 & 2001 & 2001 & $\$ 904$ \\
\hline $12 / 2 / 2001$ & $1 / 11 / 2002$ & - & 2000 & 2000 & $\$ 746$ \\
\hline $6 / 25 / 2001$ & - & - & 2000 & 2000 & $\$ 670$ \\
\hline $9 / 3 / 2002$ & $10 / 3 / 2002$ & 2003 & 2001 & 2001 & $\$ 338$ \\
\hline $10 / 1 / 2002$ & - & - & 2001 & 2001 & $\$ 333$ \\
\hline
\end{tabular}




\section{Appendix Table 2: Comparison of Time-Series Returns}

Within-Plan Mean Returns Through Year

\begin{tabular}{rrrr} 
& \multicolumn{3}{c}{ Terminating } \\
\cline { 2 - 4 } Year of & & $\begin{array}{r}\text { Standard } \\
\text { Deviation }\end{array}$ & Count \\
Termination & Mean & $2.7 \%$ & \\
\cline { 2 - 4 } 1989 & $8.8 \%$ & $9.6 \%$ & 1 \\
1990 & $11.7 \%$ & $2.7 \%$ & 3 \\
1991 & $8.4 \%$ & $4.3 \%$ & 3 \\
1992 & $9.0 \%$ & $4.7 \%$ & 4 \\
1993 & $6.8 \%$ & $3.2 \%$ & 4 \\
1994 & $7.9 \%$ & $4.4 \%$ & 28 \\
1995 & $8.2 \%$ & $2.6 \%$ & 2 \\
1996 & $8.2 \%$ & $6.0 \%$ & 3 \\
1997 & $8.6 \%$ & $3.0 \%$ & 3 \\
1998 & $9.2 \%$ & $4.4 \%$ & 33 \\
1999 & $9.7 \%$ & $2.2 \%$ & 25 \\
2000 & $9.2 \%$ & $3.6 \%$ & 5 \\
2001 & $9.9 \%$ & $3.6 \%$ & 80 \\
2002 & $8.1 \%$ & $5.5 \%$ & 98 \\
2003 & $7.0 \%$ & $4.6 \%$ & 91 \\
2004 & $6.8 \%$ & $3.8 \%$ & 59 \\
2005 & $8.2 \%$ & $4.4 \%$ & 678 \\
All & $8.2 \%$ & $4.0 \%$ & 678 \\
All†† & $-1.3 \%$ & &
\end{tabular}

\begin{tabular}{|c|c|c|c|c|}
\hline \multicolumn{3}{|c|}{ Non-Terminating } & \multirow{2}{*}{$\begin{array}{c}\text { Test of } \\
\text { Equal } \\
\text { Means }\end{array}$} & \multirow{2}{*}{$\begin{array}{c}\text { Test of } \\
\text { Equal } \\
\text { Standard } \\
\text { Deviations }\end{array}$} \\
\hline Mean & $\begin{array}{r}\text { Standard } \\
\text { Deviation }\end{array}$ & Count & & \\
\hline $12.4 \%$ & $12.4 \%$ & 12,347 & 0.0423 & 0.0087 \\
\hline $8.2 \%$ & $12.0 \%$ & 15,435 & 0.2302 & 0.3980 \\
\hline $11.7 \%$ & $9.6 \%$ & 16,865 & 0.0000 & 0.0000 \\
\hline $10.6 \%$ & $9.5 \%$ & 14,684 & 0.0338 & 0.0000 \\
\hline $10.6 \%$ & $7.0 \%$ & 15,764 & 0.0000 & 0.0016 \\
\hline $8.4 \%$ & $7.7 \%$ & 15,845 & 0.2288 & 0.0000 \\
\hline $10.4 \%$ & $7.8 \%$ & 14,411 & 0.0149 & 0.0006 \\
\hline $10.7 \%$ & $7.0 \%$ & 14,658 & 0.0000 & 0.0000 \\
\hline $11.5 \%$ & $6.2 \%$ & 13,757 & 0.0137 & 0.8536 \\
\hline $11.6 \%$ & $5.7 \%$ & 12,957 & 0.0001 & 0.0001 \\
\hline $11.5 \%$ & $5.3 \%$ & 10,121 & 0.0252 & 0.1784 \\
\hline $9.7 \%$ & $5.4 \%$ & 10,653 & 0.2403 & 0.0000 \\
\hline $7.5 \%$ & $5.5 \%$ & 11,414 & 0.0000 & 0.0002 \\
\hline $5.8 \%$ & $5.5 \%$ & 10,901 & 0.0000 & 0.0000 \\
\hline $7.1 \%$ & $4.1 \%$ & 10,264 & 0.8965 & 0.0000 \\
\hline- & - & - & $0.4756 \dagger$ & $0.0903 \dagger$ \\
\hline- & - & - & $0.0350 \dagger$ & $0.5104 \dagger$ \\
\hline $8.7 \%$ & $6.0 \%$ & 23,391 & 0.0038 & 0.0000 \\
\hline $0.0 \%$ & $5.4 \%$ & 23,391 & 0.0000 & 0.0000 \\
\hline
\end{tabular}

Within-Plan Standard Deviation of Returns Through Year

\begin{tabular}{|c|c|c|c|c|c|c|c|c|}
\hline \multirow[b]{2}{*}{$\begin{array}{r}\text { Year of } \\
\text { Termination }\end{array}$} & \multicolumn{3}{|c|}{ Terminating } & \multicolumn{3}{|c|}{ Non-Terminating } & \multirow{2}{*}{$\begin{array}{c}\text { Test of } \\
\text { Equal } \\
\text { Means }\end{array}$} & \multirow{2}{*}{$\begin{array}{c}\text { Test of } \\
\text { Equal } \\
\text { Standard } \\
\text { Deviations }\end{array}$} \\
\hline & Mean & $\begin{array}{r}\text { Standard } \\
\text { Deviation }\end{array}$ & Count & Mean & $\begin{array}{r}\text { Standard } \\
\text { Deviation }\end{array}$ & Count & & \\
\hline 1989 & $3.4 \%$ & $0.9 \%$ & 3 & $4.9 \%$ & $14.0 \%$ & 8,150 & 0.0846 & 0.0076 \\
\hline 1990 & $9.8 \%$ & $17.8 \%$ & 9 & $7.0 \%$ & $13.9 \%$ & 11,490 & 0.6508 & 0.2181 \\
\hline 1991 & $5.7 \%$ & $3.7 \%$ & 34 & $8.3 \%$ & $12.8 \%$ & 15,111 & 0.0003 & 0.0000 \\
\hline 1992 & $5.9 \%$ & $4.9 \%$ & 36 & $7.2 \%$ & $11.4 \%$ & 13,888 & 0.1079 & 0.0000 \\
\hline 1993 & $7.7 \%$ & $9.1 \%$ & 41 & $6.6 \%$ & $10.8 \%$ & 14,995 & 0.4350 & 0.1789 \\
\hline 1994 & $5.1 \%$ & $5.0 \%$ & 46 & $7.4 \%$ & $9.5 \%$ & 15,242 & 0.0029 & 0.0000 \\
\hline 1995 & $6.5 \%$ & $7.3 \%$ & 28 & $8.5 \%$ & $9.9 \%$ & 13,843 & 0.1554 & 0.0521 \\
\hline 1996 & $6.4 \%$ & $3.4 \%$ & 29 & $8.0 \%$ & $9.7 \%$ & 14,095 & 0.0187 & 0.0000 \\
\hline 1997 & $7.9 \%$ & $6.4 \%$ & 31 & $7.9 \%$ & $9.9 \%$ & 13,227 & 0.9670 & 0.0049 \\
\hline 1998 & $5.7 \%$ & $5.1 \%$ & 30 & $7.8 \%$ & $9.0 \%$ & 12,411 & 0.0333 & 0.0004 \\
\hline 1999 & $6.6 \%$ & $4.2 \%$ & 33 & $7.7 \%$ & $8.3 \%$ & 9,550 & 0.1381 & 0.0000 \\
\hline 2000 & $5.6 \%$ & $2.4 \%$ & 25 & $8.4 \%$ & $7.6 \%$ & 10,017 & 0.0000 & 0.0000 \\
\hline 2001 & $8.4 \%$ & $4.5 \%$ & 52 & $9.1 \%$ & $7.3 \%$ & 10,918 & 0.2454 & 0.0000 \\
\hline 2002 & $8.7 \%$ & $3.5 \%$ & 80 & $9.8 \%$ & $6.9 \%$ & 10,901 & 0.0058 & 0.0000 \\
\hline 2003 & $11.4 \%$ & $9.3 \%$ & 98 & $10.7 \%$ & $6.8 \%$ & 10,264 & 0.4820 & 0.0000 \\
\hline 2004 & $9.8 \%$ & $6.4 \%$ & 91 & - & - & - & $0.2000 \dagger$ & $0.4831 \dagger$ \\
\hline 2005 & $11.6 \%$ & $4.0 \%$ & 59 & - & - & - & $0.0929 \dagger$ & $0.0000 \dagger$ \\
\hline All & $8.0 \%$ & $6.6 \%$ & 670 & $9.4 \%$ & $10.1 \%$ & 23,391 & 0.0000 & 0.0000 \\
\hline
\end{tabular}

$\dagger$ Test is relative to the within-plan sample moment (mean or standard deviation) including all years through 2003.

$\dagger$ Net of year effects 
Figure 1: Pension Fund Asset Allocation in IRS 5500 Data
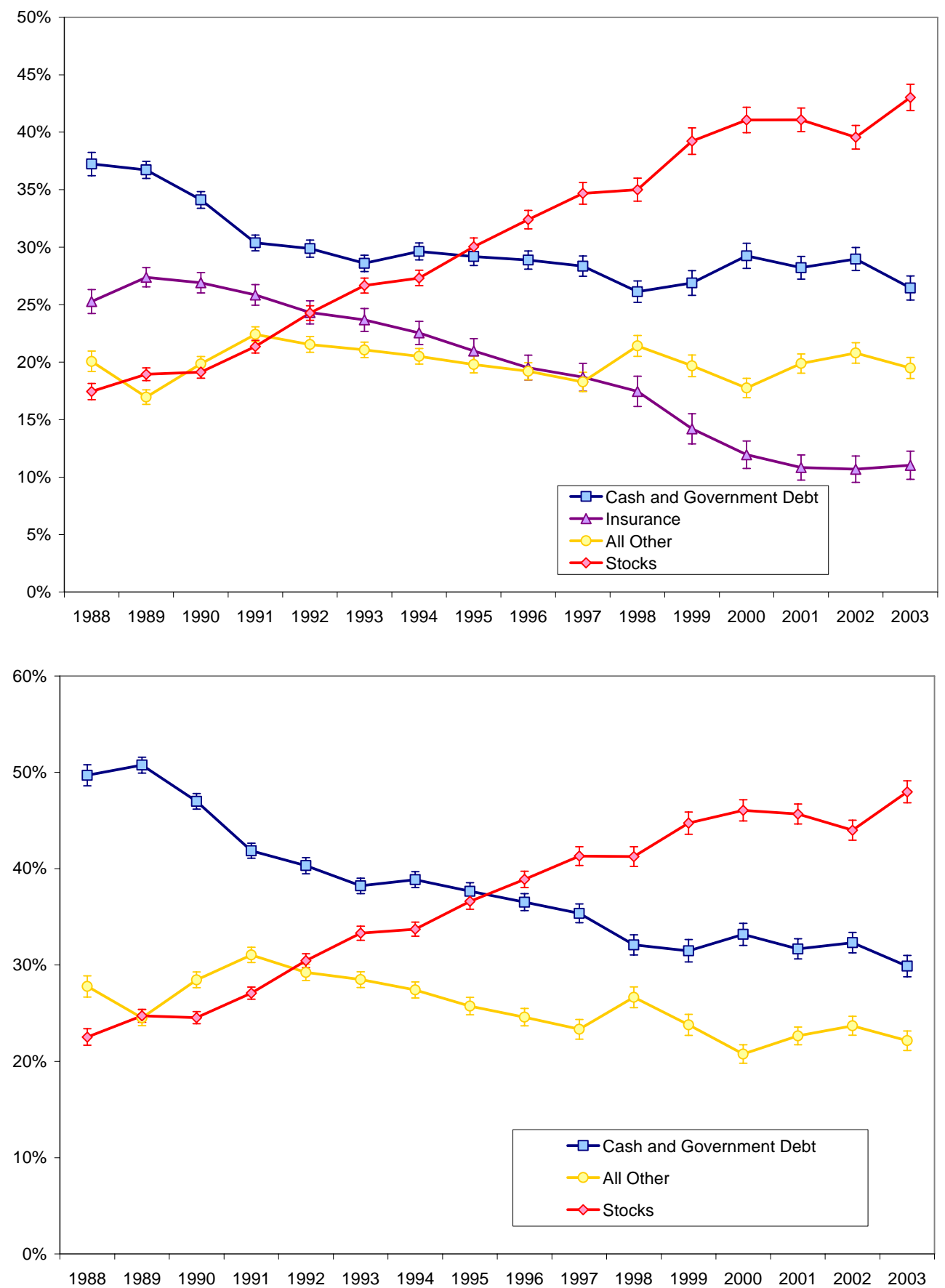
Figure 2: Effects of Funding Status on Asset Allocation in IRS 5500 Data
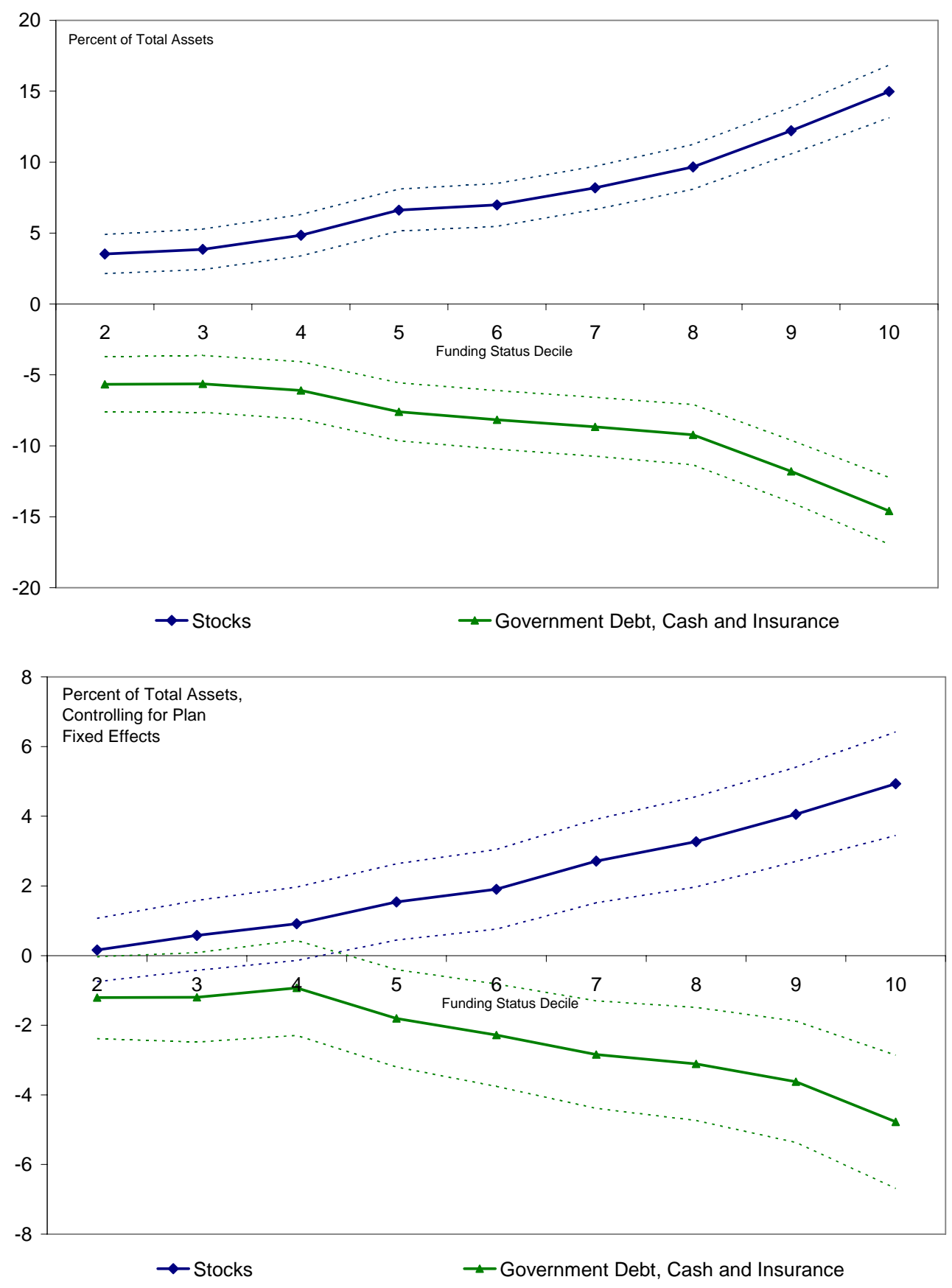
Figure 3: Distress Termination Probabilities and Asset Allocation in IRS 5500 Data

Equity Allocation (Left Scale) $\rightarrow$ Government Cash, Debt, and Insurance Allocation (Left Scale) $\rightarrow$ Probability of Termination (Right Scale)
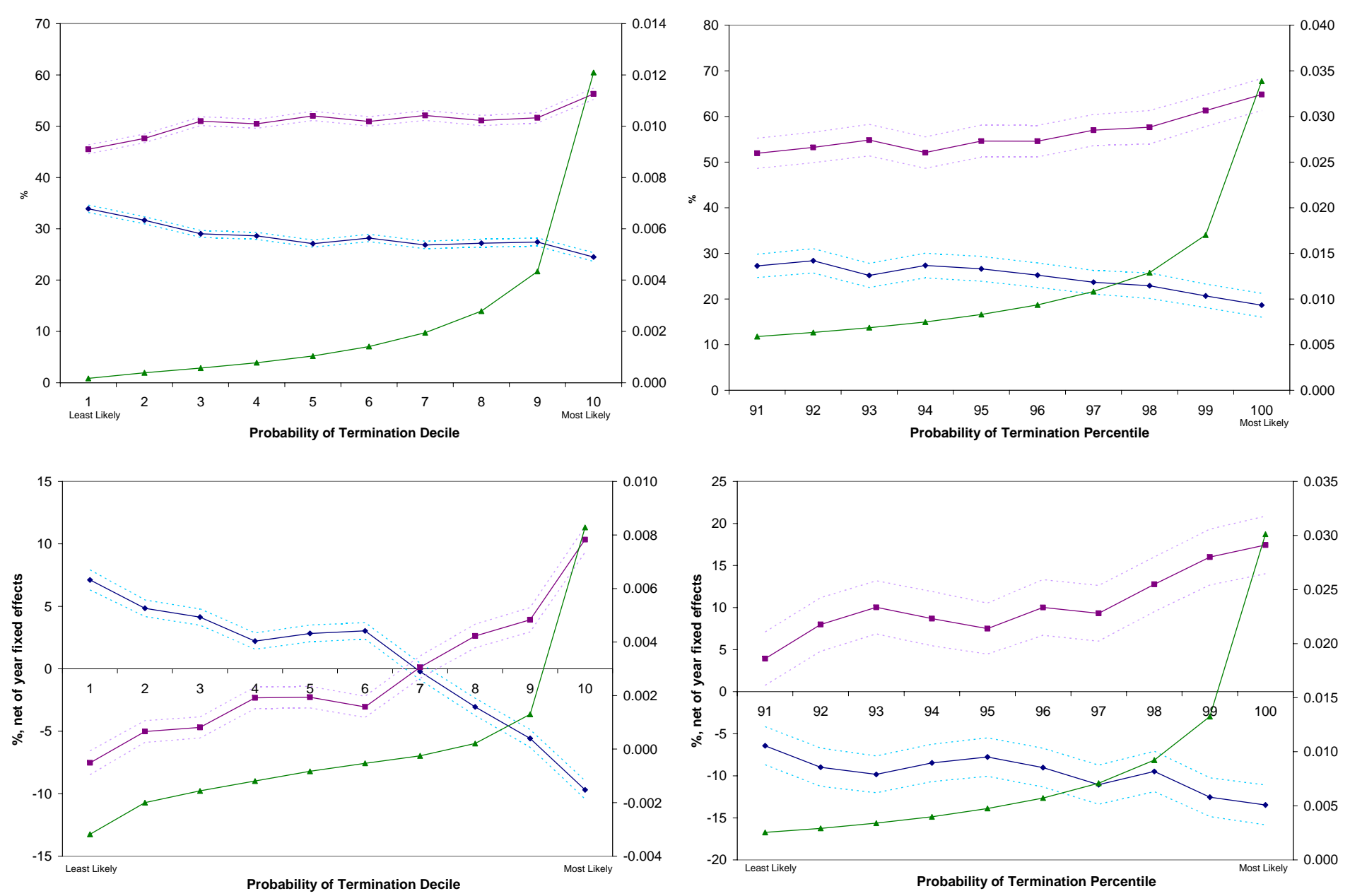
Figure 4: Bankruptcy Probabilities and Asset Allocation in Firm-Level Data

$\multimap$ Equity Allocation (Left Scale) $\rightarrow-$ Government Cash, Debt, and Insurance Allocation (Left Scale) $\rightarrow$ Probability of Termination (Right Scale)
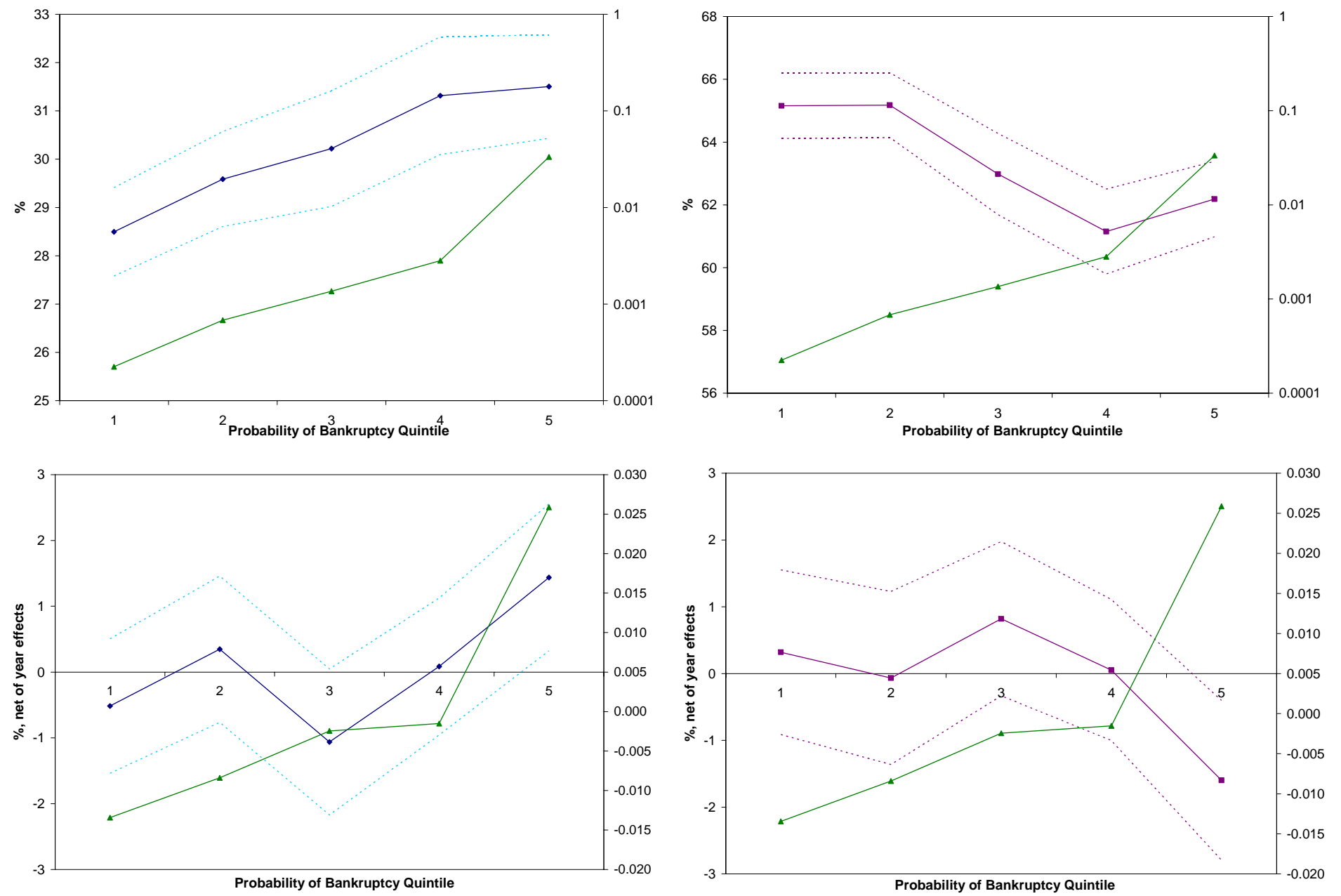
Figure 5: Investment Returns of the PBGC and the Private Sector
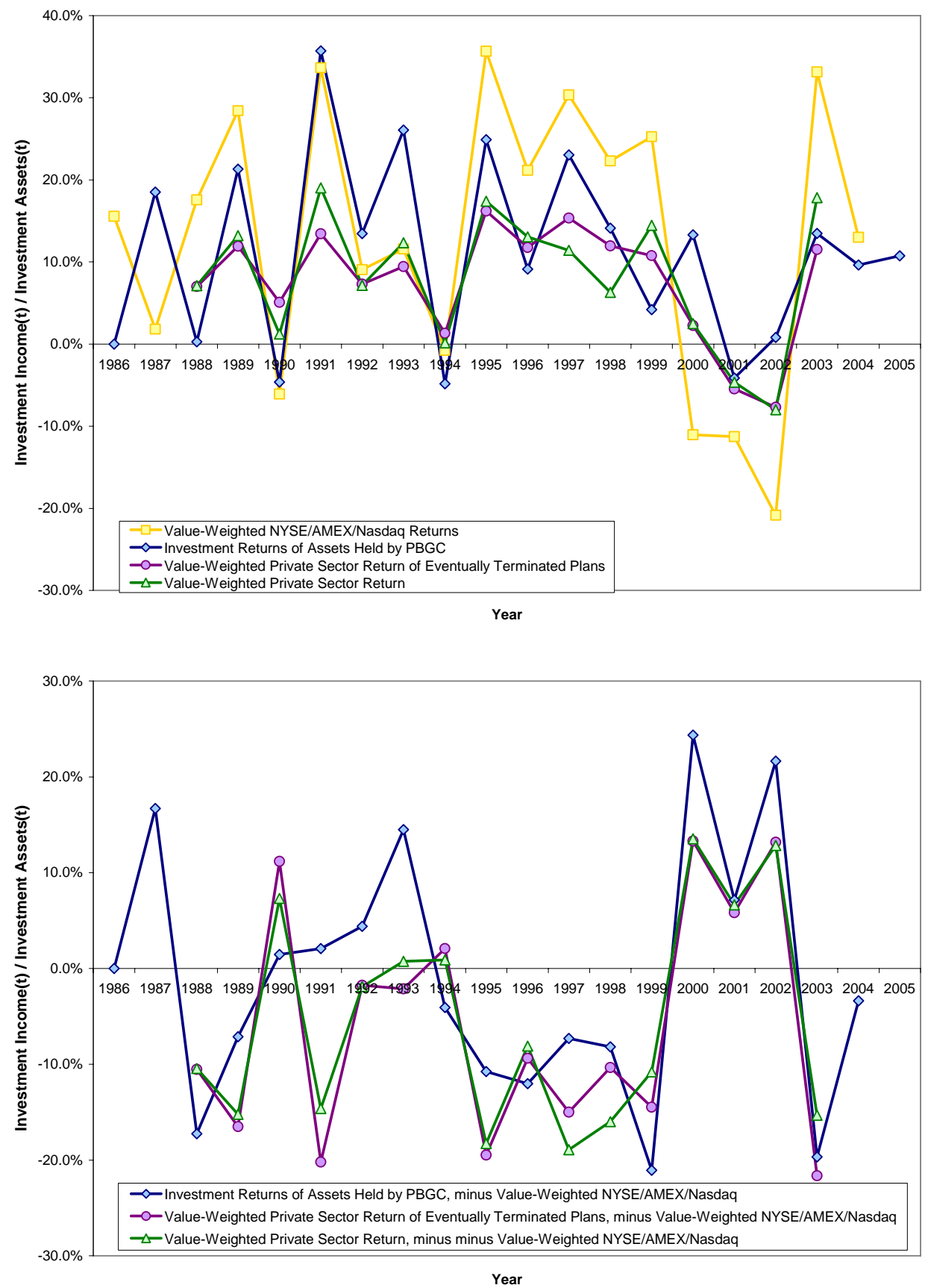